\title{
Synthesis and biological evaluation of new cephalosporin derivatives containing cyclic disulfide moieties
}

Inga S. Shchelik and Karl Gademann*

Department of Chemistry, University of Zurich, Winterthurerstrasse 190, 8057 Zurich, Switzerland

e-mail: karl.gademann@uzh.ch

\begin{abstract}
Due to a steady increase of microbial resistance, there is a need to increase the effectiveness of antibiotic performance by involving additional mechanisms of their penetration or retention for their better action. Cephalosporins are a successful group of antibiotics to combat pathogenic microorganisms, including drug-resistant strains. In this study, we investigated the effect of newly synthesized cephalosporin derivatives with cyclic disulfide modifications against several Gram-positive and Gram-negative strains as well as against biofilm formation. The incorporation of asparagusic acid was found to be effective in improving the activity of the drug against Gramnegative strains. Furthermore, we could demonstrate the successful inhibition of biofilm formation for $S$. aureus and $P$. aeruginosa at similar concentrations as obtained against planktonic cells. We propose that the incorporation of cyclic disulfides is one additional strategy to improve antibiotic activity and to combat bacterial infections.
\end{abstract}




\section{Introduction}

Over the last decades, the understanding of the relevant biological pathways and targets for antibiotic activity has been significantly expanded. Historically, activity on the bacterial target was most importantly optimized and has been constantly improved by molecular design, ${ }^{1-3}$ synthetic chemistry, ${ }^{3-5}$ and analytical techniques up to recently introduced cryo EM structure determination. ${ }^{6}$ Less studied but equally important, several additional factors strongly contribute to overall antibiotic performance, including bacterial uptake of antibiotics, their biotransformation to inactive substances, the active efflux of those agents by bacteria, and others. ${ }^{7,8}$ As a consequence, performance enhancement of antibiotics has recently enlarged to also include these aspects. Several strategies are currently employed to increase uptake of antibiotics: For example, the "Trojan horse" approach exploits receptor-mediated Fe-uptake mechanisms in bacteria, culminating in the launch of the cephalosporin-based antibiotic cefiderocol on the market. ${ }^{9,10}$ Alternatively, influx can be enhanced by the self-promoted uptake mechanism with polycationic antibiotics involving the displacement of the divalent cations that stabilize the lipopolysaccharides (LPS) membrane packing, thereby increasing the passage of the promoter into the periplasm. ${ }^{11}$ Moreover, some efforts were made to investigate the dithiolmediated uptake of antibiotics by bacteria ${ }^{12}$ in a similar manner to eukaryotic cells, ${ }^{13}$ however the obtained results have been mixed so far. Another important aspect is the formation of biofilms, which renders the producing bacteria highly recalcitrant to antibiotics. ${ }^{14}$ Biofilms are produced upon switching of the bacterial growth mode from planktonic to sessile, where the bacteria aggregate and create a mesh-like structure with extracellular substance. ${ }^{15}$ In recent years, novel therapeutic strategies were developed, where different classes of antimicrobials are able to interfere at different levels with the formation of biofilms ${ }^{16}$, including disulfide containing compounds. ${ }^{17,18}$ In an earlier study reported by us, we demonstrated that introducing sulfur-containing moieties into the antibiotic vancomycin achieved potent antibacterial activity against resistant Enterococcus and Gram-negative M. catarrhalis. Moreover, the obtained derivatives featured improved activity against biofilm formation. ${ }^{19}$ In this study, we extended this concept to a broad series of cephalosporin derivatives with cyclic disulfide moieties and their full carbon analogs to closer investigate the potential of such modifications on biological activity of the drug. Moreover, a BODIPY derivative with lipoic acid was designed to investigate the 
influence of compounds containing cyclic disulfides on the interactions with Gram-negative bacteria.
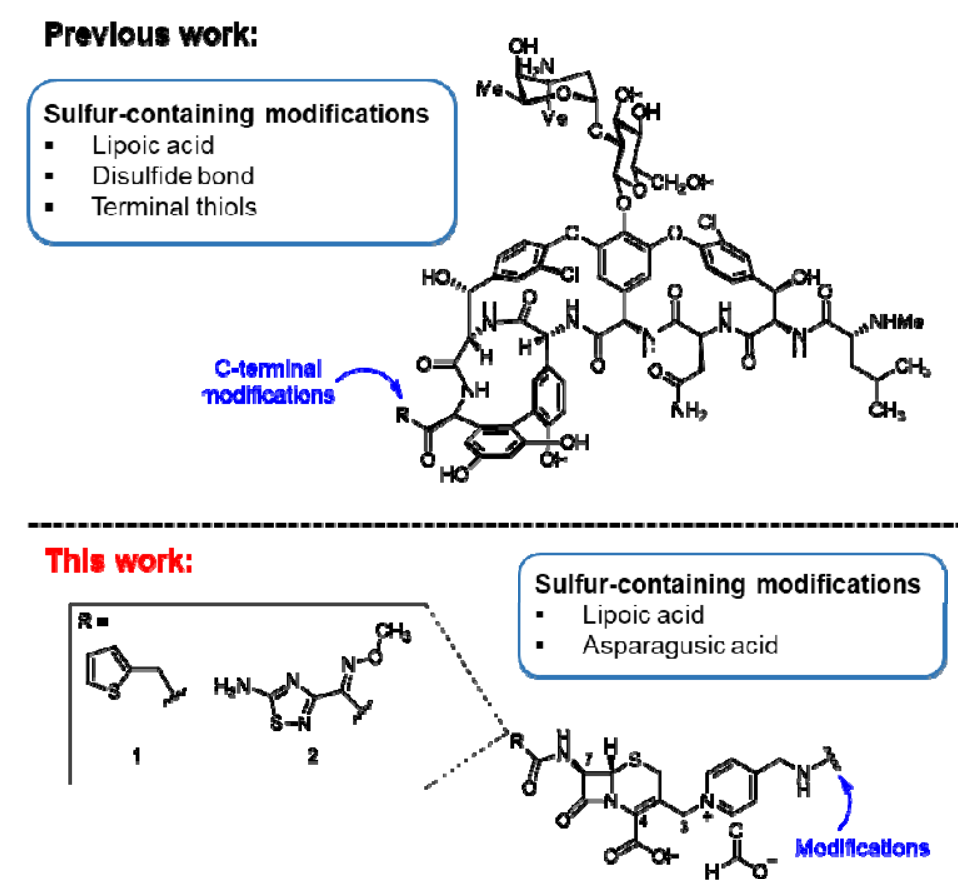

Figure 1. Sulfur-containing modification of different antibiotics. Top: Previous work on vancomycin modifications. Bottom: This work on cephalosporin modifications.

\section{Results}

\section{Design}

Cephalosporins are a class of $\beta$-lactam antibiotics originally derived from the mold Emericellopsis minimum (formerly Cephalosporium acremonium) ${ }^{20,21}$ Cephalosporins contain a six-member dihydrothiazine ring attached to the $\beta$-lactam part. They have the same mechanism of action as $\beta$ lactam antibiotics. By mimicking the D-Ala-D-Ala site of peptidoglycan precursor, cephalosporins bind penicillin binding protein (PBP) thereby irreversibly inhibiting PBP crosslinking of peptidoglycan and disrupting bacterial cell wall structural integrity. ${ }^{22}$ The biological activity of these antibiotics can be varied depending on modifications at $\mathrm{C} 3, \mathrm{C} 4$, and $\mathrm{C} 7$ positions. In our research, thiophene (1) and amino-thiadiazol (2) based side chains were chosen for the variation of the C7position of the cephalosporin core. The thiophene moiety is found in several examples of $1^{\text {st }}$ and $2^{\text {nd }}$ generation cephalosporins, which are mainly active against Gram-positive bacteria. On the other hand, the presence of amino-thiadiazol side chain represents a key structural unit for the $4^{\text {th }}$ and $5^{\text {th }}$ generation derivatives, which demonstrated and increased activity against Gram-negative strains. ${ }^{23}$ To introduce the zwitterionic properties in cephalosporin the modification at the C3'- 
position of the cepham ring was done with the incorporation of the quaternary ammonium moiety. ${ }^{24}$ Pyridinium substitution, found in several clinically used antibiotics of $1^{\text {st }}$ and $3^{\text {rd }}$ generation, was chosen using 4-(aminomethyl)pyridine, which is suitable for introducing the desired linkers via amide bond formation.

The synthesis of cephalosporin derivatives with the thiophene side chain started from cephalothin (3), which was treated with N-Methyl-N-(trimethylsilyl) trifluoroacetamide (MSTFA) followed by the addition of trimethylsilyl iodide (TMSI). Dichloromethane was removed after $1 \mathrm{~h}$ of stirring and the pyridine derivatives $4,5,6,7$, or 8 dissolved in DMF were added to access the desired products. The derivative with pyridinium moiety $\mathbf{1 1}$ lacking the additional linkers attached was prepared as the control compound from its Boc-protected precursor $\mathbf{1 0}$ by the deprotection reaction in acidic conditions. The derivatives including lipoic and asparagusic acid moieties $(\mathbf{1 2 b}, \mathbf{1 3 b})$ were prepared for the closer investigation of possible dithiol-mediated uptake of cephalosporin by Gram-negative strains. Moreover, the full-carbon analogs (12a, 13a) were also synthesized as control compounds to explore the necessity of disulfide bond incorporation for the improving of the obtained antibiotics activity. The reaction of cefalotin 3 with the linker 7 led to the formation of several by-products, which were not possible to separate from the desired compound. Therefore, the asparagusic acid derivative of cephalosporin with a thiophene side chain was obtained through intermediate 14, which, after Boc deprotection and oxidation reactions, resulted in the formation of the desired product $\mathbf{1 3 b}$ (Scheme 1, A).

The synthesis of the desired derivatives of cephalosporin with an amino-thiadiazol side chain started from the substitution of cephalosporin core 15 with pyridine derivatives $4,5,6,7$ and 8 via three straightforward steps without the isolation of intermediates, leading to the scope of disulfide-containing products $(\mathbf{1 7 b}, \mathbf{1 8 b})$, their full-carbon analogs $(\mathbf{1 7 a}, \mathbf{1 8 a})$, and the control compound with only the pyridinium moiety attached (16) (Scheme 1, B). 
A
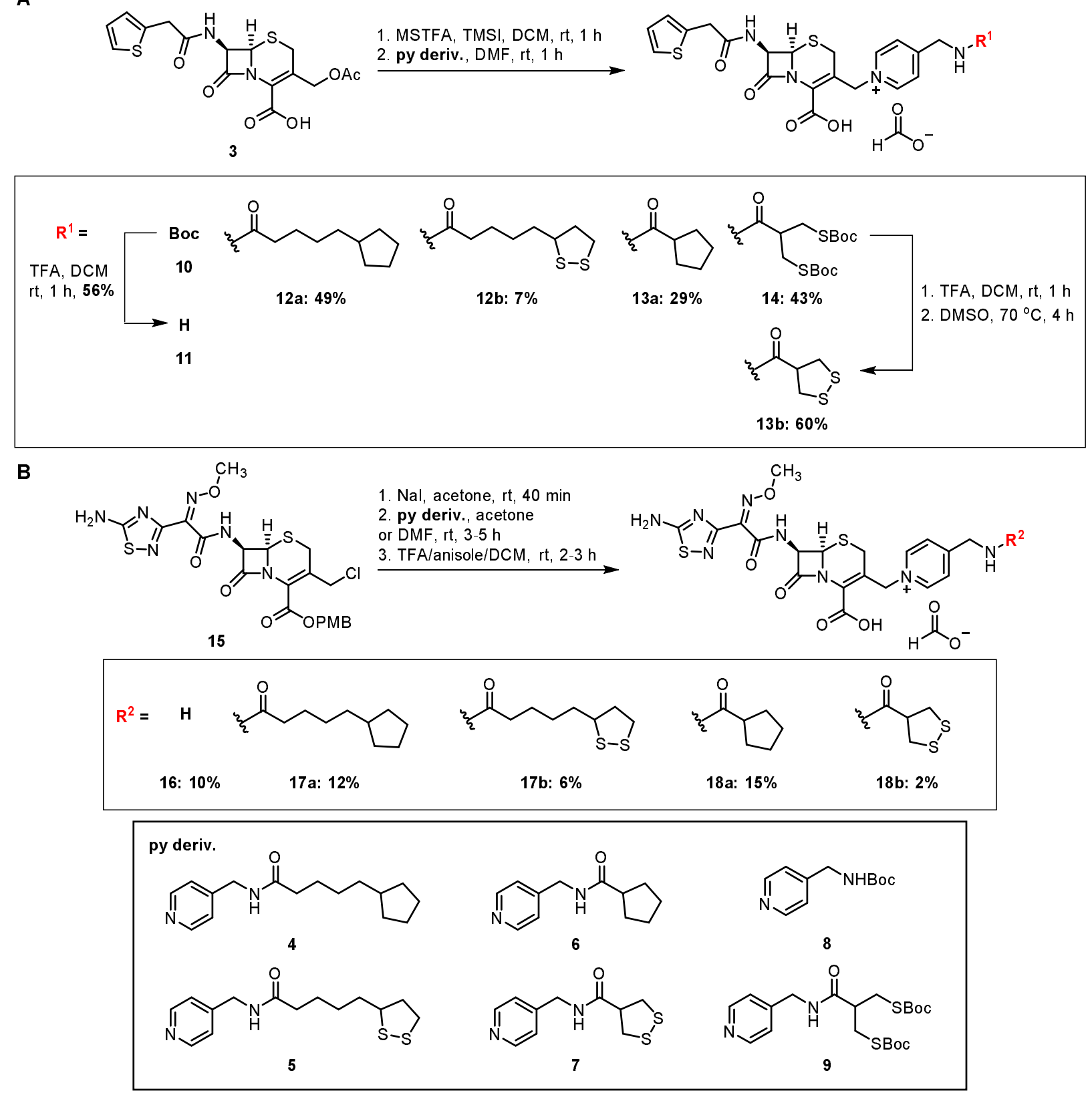

Scheme 1. Functionalization of cephalosporins. A. Synthesis of cephalosporin derivatives containing thiophene side chain. B. Synthesis of cephalosporin derivatives containing amino thiadiazol side chain.

\section{Antibacterial activity}

The antibacterial activity of obtained cephalosporin derivatives was determined against a selection of pathogenic and clinically isolated Gram-positive and Gram-negative strains by standard broth microdilution susceptibility tests. ${ }^{25}$ The data is summarized in Table 1 (more data are presented in Table S1-S2, Supporting Information). 
Thiophene-containing cephalosporin derivatives featuring elongated side chains (12 and 13) displayed an increase in antibacterial activity when tested against S. aureus and B. subtilis sensitive strains compared to control compound 11. In contrast, loss in activity was observed for the derivative with lipoic acid 12a and its full-carbon analog 12b against Gram-negative E. coli. No activity was detected for the obtained derivatives against $P$. aeruginosa, which is fully correlated with the data for previously reported cephalosporin derivatives with thiophene modification at the C-7-position of the cepham core. ${ }^{26}$ The activity of cephalosporin derivatives of the amino-thiadiazol side-chain series was mostly detected for Gram-negative strains (see control compound 16). However, the incorporation of lipoic acid-based side chain significantly decreased the activities against $E$. coli and $P$. aeruginosa. The similar effect was observed for its full-carbon analog 17a. On the other hand, an 8-fold higher activity was found for the asparagusic acid-containing compound $\mathbf{1 8 b}$ compared to its non-disulfide analog 18a when tested against $E$. coli and almost no loss in activity compared to the control compound 16 (Table 1). A strong decrease in activity was observed among the compounds with substitutions on pyridinium linker $(\mathbf{1 7 a}, \mathbf{1 7 b}, \mathbf{1 8 a})$ against Pseudomonas strains, compared to the control compound 16. Exceptionally, only 2-4-fold decline in activity was observed for the compound $\mathbf{1 8 b}$ with the asparagusic acid modification.

\begin{tabular}{|c|c|c|c|c|c|c|c|}
\hline & \multicolumn{7}{|c|}{$\mathrm{MIC}(\mu \mathrm{g} / \mathrm{mL})$} \\
\hline & S. aureus $\mathrm{s}^{\mathrm{a}}$ & S. aureus & B. subtilis ${ }^{\mathrm{c}}$ & E. coli $^{\mathrm{d}}$ & E. coli $^{\mathrm{e}}$ & P. aeruginosa & PAO1 \\
\hline 11 & 0.5 & $2-4$ & 1 & 8 & $4-8$ & $>64$ & $>64$ \\
\hline $12 \mathbf{a}$ & 0.06 & $1-2$ & 0.125 & $>64$ & $>64$ & $>64$ & $>64$ \\
\hline $12 b$ & 0.06 & 1 & $0.125-0.25$ & $>64$ & $>64$ & $>64$ & $>64$ \\
\hline 13a & 0.25 & 4 & 0.25 & 32 & 32 & $>64$ & $>64$ \\
\hline $13 b$ & 0.25 & $1-2$ & 0.25 & 16 & 8 & $>64$ & $>64$ \\
\hline 16 & 4 & 32 & $2-4$ & $1-2$ & $0.25-0.5$ & $2-4$ & $2-4$ \\
\hline $17 \mathbf{a}$ & 16 & 16 & 32 & $32-64$ & 32 & $>64$ & $>64$ \\
\hline $17 b$ & $8-16$ & $16-32$ & 4 & 16 & 64 & 64 & 64 \\
\hline $18 a$ & $32-64$ & $>64$ & $8-16$ & $16-32$ & 8 & $32-64$ & 32 \\
\hline $18 b$ & $>64$ & 32 & 4 & $2-4$ & 1 & $16-32$ & 8 \\
\hline
\end{tabular}

Table 1. Antimicrobial activity of cephalosporin derivatives. Compounds XXa are featuring cyclic disulfides and compounds XXb are the full-carbon control compounds. ${ }^{\mathrm{a}}$ ATCC $25923,{ }^{\mathrm{b}}$ ATCC $43300,{ }^{\mathrm{c}}$ ATCC $6633,{ }^{\mathrm{d}}$ ATCC 25922, ${ }^{\mathrm{e}} \mathrm{K} 12 \mathrm{MG} 1622,{ }^{\mathrm{f}} \mathrm{ATCC} 27853$. 


\section{Antibiofilm formation activity}

Approximately $80 \%$ of pathogens that form biofilms are associated with persistent infections. The typical examples of such pathogens are P. aeruginosa, which is associated with cystic fibrosis, ${ }^{27}$ and $S$. aureus, which is responsible for wound infections. ${ }^{28}$ There are several examples of natural and synthetically obtained disulfide-containing antibacterials displaying the activity against biofilm formation. For example, the studies of methyl disulfide ${ }^{18}$ showed the inhibitory effect of the compounds against Mycobacterium smegmatis biofilm formation.

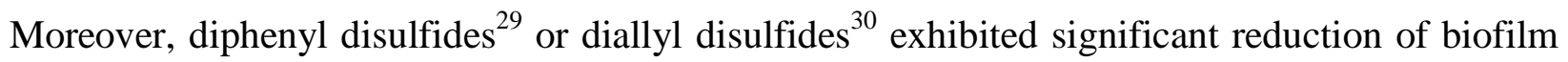
formation in Pseudomonas strains related to quorum sensing inhibition. ${ }^{31}$ Therefore, in our work, we decided to investigate the influence of the disulfide bond present in the structure of newly obtained cephalosporin derivatives on the biofilm formation of several Gram-positive and Gramnegative strains.

\section{Assessment of biofilm biomass}

Earlier in our group, the biofilm-forming activity of six Gram-positive strains was investigated in different media. Strong biofilm formation was observed for S. aureus and E. faecalis strains in Brain Heart Infusion media with the addition of $1 \%$ glucose. ${ }^{19}$ In this study, we focused on the biofilm formation of Gram-negative bacteria. E. coli and Pseudomonas were grown in eight different media: MHB, TS, TSG, TS2G, BHI, BHIG, M63, M63A for $24 \mathrm{~h}^{32}$ The assessment of biofilm production was carried out by crystal violet (CV) staining.

From the obtained results, biomass as measured by the absorbance of CV at $570 \mathrm{~nm}$ displayed low values for E. coli strains (lower 0.5) in all tested mediums. Pseudomonas featured excellent biofilm formation in M63 medium reported earlier. ${ }^{33}$ The replacement of glucose and casamino acids in M63 medium by arginine (M63A) initiated the better biofilm formation. However, the absorbance of $\mathrm{CV}$ measured in M63A medium for PAO1 was relatively low in comparison to P. aeruginosa ATCC 27853, with values ranging from 1.0 to 1.6 , in contrast to 5.1 to 6.9 , respectively (Figure 2). From the obtained results P. aeruginosa ATCC 27853 strain was chosen as a strong biofilm producer in M63 medium supplemented with arginine for the further investigation of antibiofilm formation activity of newly obtained cephalosporin derivatives. 


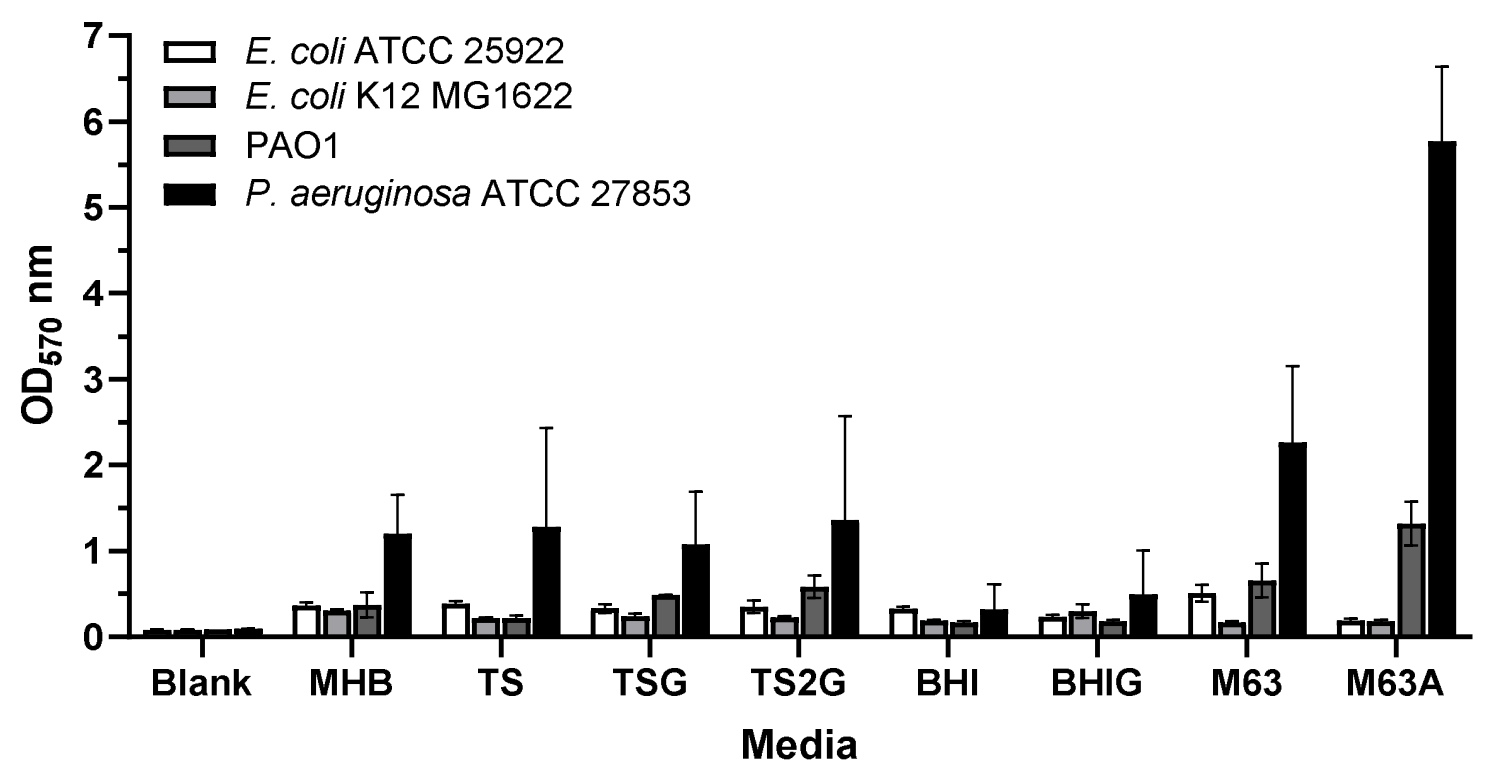

Figure 2. Assessment of biofilm biomass by crystal violet staining of 4 Gram-negative strains: E. coli ATCC 25922, E. coli K12 MG1622, PAO1, P. aeruginosa ATCC 27853. Strains were incubated in eight different media. Error bars represent standard deviation of two independent experiments in triplicate.

\section{Assessment of metabolic activity of biofilm cells by fluorescein diacetate (FDA).}

For the assessment of metabolic activity of the Pseudomonas biofilms the fluorescein diacetate (FDA) was chosen as an excellent dye when tested against Gram-negative strain. ${ }^{34}$ Biofilms were formed in $24 \mathrm{~h}$ before FDA assay. The formed biofilms were treated with FDA solutions at concentrations 2, 4 and $8 \mu \mathrm{g} / \mathrm{mL}$ and the plates were incubated at $37{ }^{\circ} \mathrm{C}$. The relative fluorescence units (RFU) were taken every 2 min for 2 h. P. aeruginosa showed increase in RFU values during $120 \mathrm{~min}$ (Figure S1 in the Supporting Information). The selection of optimal assay conditions was based on calculated statistical quality parameters (Table S3 in the Supporting Information). The excellent $Z^{\prime}$ value was obtained only at concentration $2 \mu \mathrm{g} / \mathrm{mL}$, the high variability was observed between replicates at concentrations 4 or $8 \mu \mathrm{g} / \mathrm{mL}$. According to the obtained results the conditions for the FDA assay are $2 \mu \mathrm{g} / \mathrm{mL}$ with incubation for $60 \mathrm{~min}$ for $P$. aeruginosa ATCC 27853.

\section{MBIC determination}

Using the previously optimized assay, novel synthesized cephalosporin derivatives were tested for their ability to repress the growth and biofilm formation by four bacterial strains. The biofilms were grown in optimized conditions in the presence of antibiotics at different concentrations. After incubation, MBIC was determined by resazurin for Gram-positive strains ${ }^{19}$ 
or FDA for P. aeruginosa with the chosen conditions. Colony forming unit (CFU) was also defined to validate the results obtained with metabolic activity assessment assays.

Within cephalosporin derivatives, $1^{\text {st }}$ generation analogs showed no significant difference in MBIC values compared to MIC results when tested against Staphylococcus strains. Moreover, compounds containing disulfide bond exhibited similar results compared to the control fullcarbon derivatives. The same trend was observed for the $4^{\text {th }}$ generation cephalosporin derivatives when tested against Gram-positive strains (Table S4, Supporting Information). However, 4-fold enhancement in activity was detected for the compound with asparagusic acid moiety $\mathbf{1 8 b}$ compared to its non-disulfide analog $\mathbf{1 8 a}$ when tested against $P$. aeruginosa biofilm formation (Table 2). These results demonstrate the positive influence of the disulfide bond on biological activity of the modified antibiotic when tested against the biofilm formation of Gram-negative bacteria.

Table 2. Minimal biofilm inhibitory concentration (MBIC) determined by resazurin and cell counting methods

\begin{tabular}{|c|c|c|c|c|}
\hline \multirow[b]{2}{*}{ Bacterial strain } & \multirow[b]{2}{*}{ Antibiotic } & \multirow[b]{2}{*}{$\operatorname{MIC}(\mu \mathrm{g} / \mathrm{mL})$} & \multicolumn{2}{|c|}{$\mathrm{MBIC}(\mu \mathrm{g} / \mathrm{mL})$} \\
\hline & & & $\begin{array}{c}\text { Resazurin } \\
\text { (decrease in RFU) }\end{array}$ & $\begin{array}{c}\mathrm{CFU} / \mathrm{mL} \\
\text { (growth inhibition) }\end{array}$ \\
\hline P. aeruginosa & 16 & $2-4$ & $8(91 \%)$ & $8(99 \%)$ \\
\hline ATCC 27853 & $18 \mathbf{a}$ & $32-64$ & $64(99 \%)$ & $64(100 \%)$ \\
\hline & $18 b$ & $16-32$ & $16(96 \%)$ & $16(100 \%)$ \\
\hline
\end{tabular}

\section{Discussion}

Performance enhancement of antibiotics via facilitating drug uptake by bacteria remains an important challenge. In this study, we could demonstrate the increase of antibacterial activity against Gram-negative strains for the new cephalosporin derivative containing asparagusic acid moiety and an amino thiadiazol side chain (18b). We hypothesized that the introduction of disulfide bond led to either better penetration of antibiotic through the outer membrane or involving additional mechanism of action. The benefit of disulfide bond presence in the structure of an antibiotic was earlier demonstrated by Nicolaou and co-workers, where they showed that the removal of disulfide bond from the natural product Psammaplin A or its analogs dramatically reduces the activity of the compound against a range of pathogenic strains. ${ }^{35}$ 
An earlier study by the group of Matile reported loss of activity of several antibiotics against Gram-negative strains after the introduction of cyclic oligochalcogenides into their structure. ${ }^{12}$ In this study, a similar effect was observed after the incorporation of lipoic acid into the cephalosporin structure $(\mathbf{1 2 b}, \mathbf{1 7 b})$. However, a similar tendency was observed for the control compounds with full-carbon moieties (12a, 17a). These results suggest that the general antibiotic structural modification was not optimal and resulted in the loss of activity, regardless of the presence of the disulfide bond. In contrast, an excellent activity against Gram-positive strains was shown for the cephalosporin derivatives with a thiophene side chain after the modifications while remaining effective in repressing the biofilm formation as well. Additionally, against Gram-negative strains, an improvement in activity was observed for the cephalosporin derivative with amino thiadiazol side chain and the asparagusic acid modification (18b) when tested against Pseudomonas. However, further optimization will be required to lower the amount of the drug needed for the biofilm inhibition.

Collectively, these results demonstrate that cyclic disulfides can lead to improved activity compared to their all carbon-control compounds. Moreover, cyclic disulfides apparently are able to overcome the outer membrane of bacteria. Together with data obtained in previous research done in our group on vancomycin, ${ }^{19}$ these results clearly demonstrate the usefulness of disulfides in overcoming resistance in bacteria and biofilms, and therefore, improving antibiotic effectiveness against difficult to treat pathogens.

\section{Materials and Methods}

\section{Chemistry}

The reactions were carried out under inert gas $\left(\mathrm{N}_{2}\right.$ or $\left.\mathrm{Ar}\right)$ in oven-dried $\left(120^{\circ} \mathrm{C}\right)$ glass equipment and monitored for completion by TLC or UHPLC-MS (ESI). The chemicals and solvents for the reactions and analyses were obtained from the commercial sources and used without additional purification. DL- $\alpha$-lipoic acid, 7-ACA, GCLE, and thiophene-2-acetyl chloride, ATDA were purchased from Sigma-Aldrich, Apolo Scientific, TCI, and ABCR, respectively. The synthesis of cephalothin (3), cephalosporin derivative 15, cephalosporin derivative 16, 5-cyclopentylpentanoic acid, and 3-(acetylthio)-2-((acetylthio)methyl)propanoic acid were carried out following literature procedures. ${ }^{36-40}$ The synthesized compounds were characterized through ${ }^{1} \mathrm{H}-\mathrm{NMR}$ and ${ }^{13} \mathrm{C}$ NMR spectroscopy using Bruker Avance 500 or 400 spectrometers and $\mathrm{CDCl}_{3}, \mathrm{MeOD}_{2} \mathrm{D}_{2} \mathrm{O}$, or DMSO- $d_{6}$ as the solvents. High-resolution mass spectra (HRMS) were obtained by using 
timsTOF Pro TIMS-QTOF-MS instrument in the ESI positive mode, and the values were expressed in $m / z$. The synthesized compounds were purified either through column chromatography using glass columns packed with silica gel 60 (230-400 Mesh) purchased from Sigma-Aldrich with the solvent mixture indicated or reverse phase HPLC. Thin Layer Chromatography (TLC) was run on Merck TLC plates silica gel 60 F254 on glass plates with the indicated solvent system; the spots were visualized by UV light $(365 \mathrm{~nm})$, and stained by anisaldehyde, ninhydrin, or $\mathrm{KMnO}_{4}$ stain. Additional information about the equipment used can be found in the Supporting Information.

\section{Procedures for the synthesis of linkers for cephalosporin derivatization.}

\section{Synthesis of N-(pyridin-4-ylmethyl)cyclopentanecarboxamide}

Cyclohexane carboxylic acid $(0.191 \mathrm{~mL}, 1.76 \mathrm{mmol})$ was dissolved in dry DCM $(3 \mathrm{~mL})$ and the solution was cooled down to $0{ }^{\circ} \mathrm{C}$. A solution of oxalylchloride $(0.272 \mathrm{~mL}, 3.17 \mathrm{mmol})$ in dry DCM (3 mL) was added dropwise. The reaction mixture was allowed to warm to room temperature and was stirred for 3 hours. The solution was concentrated at reduced pressure to afford a slightly yellow solid, which was used for the next step without further purification.

The obtained cyclopentanecarbonyl chloride $(115 \mathrm{mg}, 0.867 \mathrm{mmol})$ was dissolved in dry DMF (4 mL), 4-(aminomethyl)pyridine $(0.100 \mathrm{~mL}, 0.960 \mathrm{mmol})$ was added dropwise followed by the addition of DIPEA (distilled, $0.190 \mathrm{~mL}, 1.15 \mathrm{mmol}$ ). The reaction mixture was stirred for $2 \mathrm{~h}$ and then poured into water. The aqueous phase was extracted with EtOAc $(3 \times 20 \mathrm{~mL})$, the organic phase was washed with brine, dried over $\mathrm{Na}_{2} \mathrm{SO}_{4}$, and concentrated under reduced pressure. Purification was carried out by column chromatography (DCM:MeOH 95:5). The product was obtained as an amorphous solid $(140 \mathrm{mg}, 0.867 \mathrm{mmol}, 79 \%) . \quad \mathbf{R} \boldsymbol{f}=0.32$ (DCM:MeOH 95:5). ${ }^{1} \mathbf{H}$ NMR (500 MHz, $\left.\mathrm{CDCl}_{3}\right) \delta 8.53(\mathrm{~m}, 2 \mathrm{H}), 7.17(\mathrm{~m}, 2 \mathrm{H}), 6.03(\mathrm{~s}, 1 \mathrm{H})$, $4.45(\mathrm{~d}, J=5.5 \mathrm{~Hz}, 2 \mathrm{H}), 2.59$ (p, $J=7.9 \mathrm{~Hz}, 1 \mathrm{H}), 1.98-1.67(\mathrm{~m}, 6 \mathrm{H}), 1.59(\mathrm{~m}, 2 \mathrm{H}) .{ }^{13} \mathbf{C}$ NMR $\left(126 \mathrm{MHz}_{\mathrm{CDCl}}\right) \delta 176.62,150.08,147.96,122.37,45.85,42.40,30.63,26.07$. IR (film): 3287, 2955, 1647, 1603, 1539, 1416, 1239, 794. HRMS (ESI): calcd for $\mathrm{C}_{12} \mathrm{H}_{17} \mathrm{ON}_{2}[\mathrm{M}+\mathrm{H}]^{+}$, $m / z=205.13354$, found 205.13343 .

\section{Synthesis of 3-(tritylthio)-2-[(tritylthio)methyl]propanoic acid}

Triphenylmethane thiol $(1.410 \mathrm{~g}, 5.1 \mathrm{mmol})$ was suspended in DMSO $(3 \mathrm{~mL})$ and DBU (1 mL, $6.12 \mathrm{mmol}$ ) was added. The reaction mixture turned dark orange and then a precipitate was observed. After the stirring of the reaction mixture at $\mathrm{rt}$ for $5 \mathrm{~min}$, 3-bromo-2- 
(bromethyl)propionic acid (500 mg, $2.04 \mathrm{mmol}$ ) in $1 \mathrm{ml}$ of DMSO was added dropwise. The precipitate dissolved over $2.5 \mathrm{~h}$ while stirring at $\mathrm{rt}$. A $5 \%$ solution of $\mathrm{HCl}$ in water $(20 \mathrm{~mL}) \mathrm{was}$ added dropwise to the reaction and the water phase was extracted with DCM $(3 \times 15 \mathrm{~mL})$. The organic phase was collected, dried over $\mathrm{Na}_{2} \mathrm{SO}_{4}$, and concentrated by reduced pressure. The crude mixture was purified by column chromatography (pentane:EtOAc:0.1\%TFA 4:1, 2:1, 1:1). The desired product was isolated as a white solid (715 $\mathrm{mg}, 2.04 \mathrm{mmol}, 55 \%)$.

$\mathbf{R} \boldsymbol{f}=0.8$ (pentane:EtOAc $=1: 1) .{ }^{1} \mathbf{H} \mathbf{N M R}\left(500 \mathrm{MHz}, \mathrm{CDCl}_{3}\right) \delta 7.35-7.30(\mathrm{~m}, 12 \mathrm{H}), 7.24-$ $7.21(\mathrm{~m}, 12 \mathrm{H}), 7.20-7.14(\mathrm{~m}, 6 \mathrm{H}), 2.39(\mathrm{dd}, J=12.5,7.5 \mathrm{~Hz}, 2 \mathrm{H}), 2.19(\mathrm{dd}, J=12.5,5.9 \mathrm{~Hz}$, 2H), 1.90 (p, $J=6.4 \mathrm{~Hz}, 1 \mathrm{H}) .{ }^{13} \mathbf{C} \mathbf{N M R}\left(126 \mathrm{MHz}, \mathrm{CDCl}_{3}\right) \delta 144.56,129.71,128.05,126.85$, 67.15, 32.79. IR (film): 1705, 1488, 1184, 1034, 908, 741, 699 HRMS (ESI): calcd for $\mathrm{C}_{42} \mathrm{H}_{35} \mathrm{O}_{2} \mathrm{~S}_{2}[\mathrm{M}+\mathrm{H}]^{+}, m / z=635.20840$, found 635.20873.

\section{Synthesis of N-(pyridin-4-ylmethyl)-3-(tritylthio)-2-((tritylthio)methyl)propanamide}

To a solution of 3-(tritylthio)-2-[(tritylthio)methyl]propanoic acid (174 mg, $0.273 \mathrm{mmol})$ in DMF (2.6 mL), PyBoP (284 mg, $0.546 \mathrm{mmol})$, HOBt (37 mg, $0.273 \mathrm{mmol})$, and DIPEA (0.1 $\mathrm{mL}, 0.55 \mathrm{mmol})$ were added. The reaction mixture was stirred for $2 \mathrm{~h}$ at $\mathrm{rt}$. Water $(20 \mathrm{~mL})$ was added to the mixture and the aqueous layer was extracted with DCM $(3 \times 30 \mathrm{~mL})$. The collected organic phases were dried over $\mathrm{Na}_{2} \mathrm{SO}_{4}$, and concentrated under reduced pressure. Purification was carried out by column chromatography (pentane:EtOAc 1:1, 1:2). The product was isolated as a white amorphous solid (184 $\mathrm{mg}, 0.273 \mathrm{mmol}, 93 \%)$.

$\mathbf{R} \boldsymbol{f}=0.4$ (pentane:EtOAc $=1: 2) .{ }^{1} \mathbf{H}$ NMR $\left(500 \mathrm{MHz}, \mathrm{CDCl}_{3}\right) \delta 8.45(\mathrm{dd}, J=1.5,4.5 \mathrm{~Hz}, 2 \mathrm{H})$, $7.38-7.33(\mathrm{~m}, 12 \mathrm{H}), 7.30-7.25(\mathrm{~m}, 12 \mathrm{H}), 7.24-7.19(\mathrm{~m}, 8 \mathrm{H}), 5.42(\mathrm{t}, J=6.1 \mathrm{~Hz}, 1 \mathrm{H}), 4.38$ $(\mathrm{d}, J=6.1 \mathrm{~Hz}, 2 \mathrm{H}), 2.47(\mathrm{dd}, J=12.5,8.6 \mathrm{~Hz}, 2 \mathrm{H}), 2.17(\mathrm{dd}, J=12.5,5.6 \mathrm{~Hz}, 2 \mathrm{H}), 1.36(\mathrm{tt}, J=$ 8.6, $5.6 \mathrm{~Hz}, 1 \mathrm{H}) .{ }^{13} \mathbf{C}$ NMR $\left(126 \mathrm{MHz}, \mathrm{CDCl}_{3}\right) \delta$ 172.58, 149.98, 144.62, 129.71, 128.09, 126.94, 122.49, 67.20, 66.24, 46.77, 42.40, 33.88. IR (film): 1663, 1600, 1539, 1488, 1443, 1415, 1387, 1318, 1265, 1183, 1096, 1033, 1000, 841. HRMS (ESI): calcd for $\mathrm{C}_{48} \mathrm{H}_{43} \mathrm{ON}_{2} \mathrm{~S}_{2}$ $[\mathrm{M}+\mathrm{H}]^{+}, m / z=727.28113$, found 727.28012.

\section{Synthesis of O,O'-di-tert-butyl S,S'-(2-((pyridin-4-ylmethyl)carbamoyl)propane-1,3-diyl)}

\section{bis(carbonothioate)}

N-(pyridin-4-ylmethyl)-3-(tritylthio)-2-((tritylthio)methyl)propanamide (170 mg, $0.234 \mathrm{mmol})$ was dissolved in DCM (1.2 mL) and TFA $(1.2 \mathrm{~mL}, \mathrm{v} / \mathrm{v} 50 \%)$ was added. The reaction mixture turned yellow. TES $(0.380 \mathrm{~mL}, 2.34 \mathrm{mmol})$ was added and the reaction mixture was stirred at $\mathrm{rt}$ 
under argon for $1 \mathrm{~h}$. The solvent was evaporated and the mixture was washed with pentane $(5 \times 10 \mathrm{~mL})$ until the white precipitate was completely dissolved. The deprotected product as a colorless oil was used for the next step without additional purification.

The dithiol derivative was next dissolved in $\mathrm{CH}_{3} \mathrm{CN}(2.4 \mathrm{~mL}) . \mathrm{K}_{2} \mathrm{CO}_{3}(65 \mathrm{mg}, 0.470 \mathrm{mmol})$ was added, followed by the addition of a solution of $\mathrm{Boc}_{2} \mathrm{O}(0.100 \mathrm{~mL}, 0.490 \mathrm{mmol})$ in $\mathrm{CH}_{3} \mathrm{CN}(0.2$ $\mathrm{mL}$ ). The reaction was stirred at $\mathrm{rt}$ under argon for $5 \mathrm{~h}$. The reaction mixture was concentrated under reduced pressure and DCM and water were added. The aqueous layer was extracted with DCM (15mLx3). The organic phase was washed with brine and dried over $\mathrm{Na}_{2} \mathrm{SO}_{4}$. The solvent was evaporated and the residue was purified by column chromatography (pentane:EtOAc 1:1, 1:2). The product was isolated as a yellowish amorphous solid (66 mg, $0.234 \mathrm{mmol}, 64 \%$ ).

$\mathbf{R} \boldsymbol{f}=0.25$ (pentane:EtOAc = 1:2). ${ }^{1} \mathbf{H}$ NMR (400 MHz, MeOD) $\delta 8.50-8.44(\mathrm{~m}, 2 \mathrm{H}), 7.43-$ $7.38(\mathrm{~m}, 2 \mathrm{H}), 4.45(\mathrm{~s}, 2 \mathrm{H}), 3.35(\mathrm{~s}, 1 \mathrm{H}), 3.10(\mathrm{dd}, J=13.8,5.6 \mathrm{~Hz}, 2 \mathrm{H}), 3.00(\mathrm{dd}, J=13.5,8.6$ $\mathrm{Hz}, 2 \mathrm{H}), 2.93-2.85$ (m, 1H), 1.49 (s, 18H). ${ }^{13}$ C NMR (101 MHz, MeOD) $\delta 174.88,169.83$, 150.61, 149.99, 123.96, 86.24, 43.06, 33.36, 28.44. IR (film): 2980, 2932, 1716, 1700, 1646, 1604, 1455, 1416, 1394, 1369, 1200, 1119, 833. HRMS (ESI): calcd for $\mathrm{C}_{20} \mathrm{H}_{31} \mathrm{O}_{5} \mathrm{~N}_{2} \mathrm{~S}_{2}[\mathrm{M}+\mathrm{H}]^{+}$, $m / z=443.16689$, found 443.16715 .

\section{Synthesis of S,S'-(2-((pyridin-4-ylmethyl)carbamoyl)propane-1,3-diyl) diethanethioate}

Oxalyl chloride (94 ul, $1.1 \mathrm{mmol}$ ) was added dropwise at $0{ }^{\circ} \mathrm{C}$ into the solution of 3-(acetylthio)2-((acetylthio)methyl)propanoic acid (274 mg, $1.16 \mathrm{mmol})$ in DCM (11.5 mL) in presence of catalytic amount of N,N-dimethylformamide. The reaction mixture was stirred at $0{ }^{\circ} \mathrm{C}$ for $2 \mathrm{~h}$. The solvent was evaporated under reduced pressure and the product was used for the next step without additional purification.

The obtained acid chloride (148 mg, $0.581 \mathrm{mmol})$ was dissolved in dry DMF (5.8 mL). 4(aminomethyl)pyridine $(0.065 \mathrm{~mL}, 0.6 \mathrm{mmol})$ was added dropwise into the reaction at $\mathrm{rt}$, followed by the addition of DIPEA (distilled, $108 \mathrm{ul}, 0.639 \mathrm{mmol}$ ). The reaction mixture was stirred at $\mathrm{rt}$ for $1.5 \mathrm{~h}$. The solvent was evaporated and the residue was purified by column chromatography (DCM:MeOH = 100:5). The desired product was isolated as a yellow solid (80 $\mathrm{mg}, 0.581 \mathrm{mmol}) . \mathbf{R} \boldsymbol{f}=0.35$ (DCM:MeOH = 100:5). ${ }^{1} \mathbf{H} \mathbf{N M R}\left(500 \mathrm{MHz}, \mathrm{CDCl}_{3}\right) \delta 8.58-8.54$ $(\mathrm{m}, 2 \mathrm{H}), 7.25-7.21(\mathrm{~m}, 2 \mathrm{H}), 6.46(\mathrm{t}, J=6.1 \mathrm{~Hz}, 1 \mathrm{H}), 4.48(\mathrm{~d}, J=6.0 \mathrm{~Hz}, 2 \mathrm{H}), 3.16(\mathrm{dd}, J=$ 13.8, 7.4 Hz, 2H), 3.08 (dd, $J=13.8,6.2 \mathrm{~Hz}, 2 \mathrm{H}), 2.67-2.58(\mathrm{~m}, 1 \mathrm{H}), 2.34(\mathrm{~d}, J=1.0 \mathrm{~Hz}, 6 \mathrm{H})$. ${ }^{13}$ C NMR $\left(126 \mathrm{MHz}, \mathrm{CDCl}_{3}\right) \delta 196.14,172.19,150.03,147.38,122.50,47.39,42.62,30.77$. IR 
(film): 3301, 1690, 1603, 1542, 1416, 1355, 1249, 1133, 957, 788, 625. HRMS (ESI): calcd for $\mathrm{C}_{14} \mathrm{H}_{19} \mathrm{~N}_{2} \mathrm{O}_{3} \mathrm{~S}_{2}[\mathrm{M}+\mathrm{H}]^{+}, m / z=327.08316$, found 327.08286 .

\section{Synthesis of $N$-(pyridin-4-ylmethyl)-1,2-dithiolane-4-carboxamide}

S,S'-(2-((pyridin-4-ylmethyl)carbamoyl)propane-1,3-diyl) diethanethioate (100 mg, $0.306 \mathrm{mmol})$ was dissolved in $\mathrm{MeOH}(3.06 \mathrm{~mL})$ and $\mathrm{K}_{2} \mathrm{CO}_{3}(127 \mathrm{mg}, 1 \mathrm{mmol})$ was added. The reaction mixture was stirred at $\mathrm{rt}$ for $1 \mathrm{~h}$. The solvent was evaporated and water $(20 \mathrm{~mL})$ was added. The water phase was extracted with EtOAc $(3 \times 20 \mathrm{~mL})$. The organic phase was collected, washed with brine, dried over $\mathrm{Na}_{2} \mathrm{SO}_{4}$, and concentrated by reduced pressure. The crude was dried under vacuo and then dissolved in DMSO $(1 \mathrm{~mL})$. The reaction mixture was heated to $70{ }^{\circ} \mathrm{C}$ and stirred for $12 \mathrm{~h}$ in open flask. The solvent was evaporated and the reaction mixture was purified by column chromatography (DCM:MeOH=90:10). The desired product was obtained as a slightly yellow amorphous solid (21 mg, $0.306 \mathrm{mmol}, 29 \%)$.

$\mathbf{R} \boldsymbol{f}=0.6$ (DCM:MeOH = 90:10). ${ }^{1} \mathbf{H}$ NMR $\left(500 \mathrm{MHz}, \mathrm{CDCl}_{3}\right) \delta 8.60-8.51(\mathrm{~m}, 2 \mathrm{H}), 7.21-7.13$ $(\mathrm{m}, 2 \mathrm{H}), 6.42(\mathrm{~s}, 1 \mathrm{H}), 4.47(\mathrm{~d}, J=6.0 \mathrm{~Hz}, 2 \mathrm{H}), 3.45-3.38(\mathrm{~m}, 4 \mathrm{H}), 3.37-3.32(\mathrm{~m}, 1 \mathrm{H}) .{ }^{13} \mathbf{C}$ NMR (126 MHz, $\left.\mathrm{CDCl}_{3}\right) \delta 172.17,150.31,147.03,122.35,52.39,42.84$. IR (film): 2925, 2370, 1644, 1602, 1562, 1445, 1415, 1363, 1315, 1260, 1219, 1030, 994, 796, 609, 476. HRMS (ESI): calcd for $\mathrm{C}_{10} \mathrm{H}_{13} \mathrm{ON}_{2} \mathrm{~S}_{2}[\mathrm{M}+\mathrm{H}]^{+}, m / z=241.04638$, found 241.04626 .

\section{Synthesis of 5-cyclopentyl-N-(pyridin-4-ylmethyl)pentanamide}

To a solution of 5-cyclopentylpentanoic acid (40 mg, $0.235 \mathrm{mmol})$ in DMF (2.40 mL), HATU (179 $\mathrm{mg}, 0.47 \mathrm{mmol}$ ) and DIPEA (distilled, $0.120 \mathrm{~mL}, 0.705 \mathrm{mmol}$ ) were added. The reaction mixture turned slightly brown. After $5 \mathrm{~min}$ of stirring, 4-(aminomethyl)pyridine $(0.028 \mathrm{~mL}$, $0.282 \mathrm{mmol}$ ) was added. The reaction mixture was stirred at room temperature for $1.5 \mathrm{~h}$. Water $(10 \mathrm{~mL})$ was added and the mixture was extracted with EtOAc $(4 \times 20 \mathrm{~mL})$. The combined organic layer was washed with brine, dried over $\mathrm{MgSO} 4$ and concentrated under reduced pressure. The purification carried out by column chromatography (pentane:EtOAc 1:1). The desired product was isolated as a white solid (46 $\mathrm{mg}, 0.235 \mathrm{mmol}, 75 \%)$.

$\mathbf{R} \boldsymbol{f}=0.35$ (pentane:EtOAc = 1:1). ${ }^{1} \mathbf{H}$ NMR $\left(500 \mathrm{MHz}, \mathrm{CDCl}_{3}\right) \delta 8.55(\mathrm{~d}, J=5.8 \mathrm{~Hz}, 2 \mathrm{H}), 7.18$ $(\mathrm{d}, J=6.0 \mathrm{~Hz}, 2 \mathrm{H}), 6.02-5.80(\mathrm{br}, 1 \mathrm{H}), 4.46(\mathrm{~d}, J=6.1 \mathrm{~Hz}, 2 \mathrm{H}), 2.26(\mathrm{t}, J=7.5 \mathrm{~Hz}, 2 \mathrm{H}), 1.80-$ $1.62(\mathrm{~m}, 4 \mathrm{H}), 1.62-1.54(\mathrm{~m}, 2 \mathrm{H}), 1.53-1.46(\mathrm{~m}, 2 \mathrm{H}), 1.40-1.27(\mathrm{~m}, 5 \mathrm{H}), 1.13-0.99(\mathrm{~m}$, 2H). ${ }^{13}$ C NMR $\left(126 \mathrm{MHz}, \mathrm{CDCl}_{3}\right) \delta 173.48,150.11,147.79,122.45,42.43,40.11,36.85,35.98$, 
32.82, 28.60, 26.10, 25.30. IR (film): 3284, 2926, 2857, 1652, 1528, 1351, 842, 558, 464. HRMS (APCI): $\mathrm{C}_{16} \mathrm{H}_{25} \mathrm{ON}_{2}[\mathrm{M}+\mathrm{H}]^{+}, m / z=261.19614$, found 261.19591.

\section{Synthesis of 5-(1,2-dithiolan-3-yl)-N-(pyridin-4-ylmethyl)pentanamide}

To a solution of racemic $\alpha$-lipoic acid (400 mg, $1.94 \mathrm{mmol})$ in dry DMF (18 mL), PyBOP (1.8 g, $3.52 \mathrm{mmol})$, HOBt (119 mg, $0.88 \mathrm{mmol})$, and DIPEA (1 ml, $5.28 \mathrm{mmol})$ were added. The reaction mixture was stirred for $10 \mathrm{~min}$ at $\mathrm{rt}$ followed by an addition of 4-(aminomethyl)pyridine $(0.178 \mathrm{ml}, 1.76 \mathrm{mmol})$. The reaction mixture was stirred overnight at $\mathrm{rt}$ and then the solvent was removed under reduced pressure. The purification was carried out by column chromatography (DCM: $\mathrm{MeOH}=95: 5$ ). The desired product was isolated as a yellow oil (435 $\mathrm{mg}, 1.47 \mathrm{mmol}$, $83 \%) . \mathbf{R} f=0.35$ (DCM: $\mathrm{MeOH}=95: 5){ }^{1} \mathbf{H} \mathbf{N M R}\left(500 \mathrm{MHz}, \mathrm{CDCl}_{3}\right) \delta 8.55(\mathrm{dd}, J=1.5,4.5 \mathrm{~Hz}$, 2H), $7.20(\mathrm{dd}, J=1.5,4.5 \mathrm{~Hz}, 2 \mathrm{H}), 5.91-5.85(\mathrm{~m}, 1 \mathrm{H}), 4.47(\mathrm{~d}, J=6.1 \mathrm{~Hz}, 2 \mathrm{H}), 3.61-3.54(\mathrm{~m}$, $1 \mathrm{H}), 3.21-3.08(\mathrm{~m}, 2 \mathrm{H}), 2.50-2.43(\mathrm{~m}, 1 \mathrm{H}), 2.31-2.25(\mathrm{~m}, 2 \mathrm{H}), 1.94-1.86(\mathrm{~m}, 1 \mathrm{H}), 1.80-$ $1.61(\mathrm{~m}, 4 \mathrm{H}), 1.56-1.42(\mathrm{~m}, 2 \mathrm{H}) .{ }^{13} \mathbf{C}$ NMR (126 MHz, $\left.\mathrm{CDCl}_{3}\right) \delta 173.02,150.05,147.76$, 122.50, 56.54, 42.50, 40.41, 38.64, 36.45, 34.73, 29.04, 25.45. IR (film): 3284, 3054, 2926, 2855, 1650, 1602, 1543, 1416, 1361, 1259, 1067, 1028, 792 HRMS (ESI): calcd for $\mathrm{C}_{14} \mathrm{H}_{21} \mathrm{ON}_{2} \mathrm{~S}_{2}[\mathrm{M}+\mathrm{H}]^{+}, m / z=297.10898$, found 297.10870.

\section{Procedures for the synthesis of cephalosporin derivatives with thiophene side chain.}

General procedure. Under an argon atmosphere, cephalothin (3, 1 equiv.) and MSTFA (3 equiv.) were added to dry methylene chloride $(0.1 \mathrm{M}$ solution) in a Schlenk tube, and the reaction mixture was stirred at $\mathrm{rt}$ for 15 min until a solution was observed. Iodotrimethylsilane (2 equiv.) was added and stirring was continued for another $1 \mathrm{~h}$. The mixture was concentrated under reduced pressure connected to Schlenk line, and the residual oil was dissolved in dry DMF to obtain a $0.1 \mathrm{M}$ solution. A few drops of dry THF were added and the mixture was stirred for 1 minute. The pyridine derivative dissolved in dry $\operatorname{DMF}(0.1 \mathrm{M}$ solution) was added and the reaction mixture was stirred at $\mathrm{rt}$ for $1 \mathrm{~h}$. The solvents were evaporated, and the residue was resuspended in a mixture of $\mathrm{MeOH} / \mathrm{CH}_{3} \mathrm{CN}$, filtered through a SPE column, and purified by preparative RP-HPLC to afford the desired products. The purification methods, analytical data, and yields are reported below.

Cephalosporin derivative 10. RP-HPLC (Gemini-NX, flow rate $=15 \mathrm{~mL} / \mathrm{min}$ ): Gradient $5 \% \mathrm{~B}$ for $14 \mathrm{~min}$; $0 \%$ - 50\% B for $46 \mathrm{~min}$; $50 \%$ - 100\% B for $3 \mathrm{~min}$, wash. The desired product, eluting at $28.5 \mathrm{~min}$, was collected and lyophilized to afford product $\mathbf{1 0}(21 \mathrm{mg}, 0.126 \mathrm{mmol}, 31 \%)$ as a 
white solid. ${ }^{1}$ H NMR (500 MHz, DMSO- $\left.d_{6}\right) \delta 9.40(\mathrm{~d}, J=6.5 \mathrm{~Hz}, 2 \mathrm{H}), 9.05(\mathrm{~d}, J=8.4 \mathrm{~Hz}, 1 \mathrm{H})$, $7.94(\mathrm{~d}, J=6.4 \mathrm{~Hz}, 2 \mathrm{H}), 7.72(\mathrm{t}, J=5.8 \mathrm{~Hz}, 1 \mathrm{H}), 7.35-7.33(\mathrm{dd}, J=5.1,1.3 \mathrm{~Hz}, 1 \mathrm{H}), 6.92(\mathrm{dd}$, $J=5.1,3.4 \mathrm{~Hz}, 1 \mathrm{H}), 6.89(\mathrm{dq}, J=3.4,1.1 \mathrm{~Hz}, 1 \mathrm{H}), 5.63(\mathrm{~d}, J=13.4 \mathrm{~Hz}, 1 \mathrm{H}), 5.54(\mathrm{dd}, J=8.5$, $4.8 \mathrm{~Hz}, 1 \mathrm{H}), 5.04-4.99(\mathrm{~m}, 2 \mathrm{H}), 4.41(\mathrm{~d}, J=5.9 \mathrm{~Hz}, 2 \mathrm{H}), 3.74-3.67(\mathrm{~m}, 2 \mathrm{H}), 3.51(\mathrm{~d}, J=17.6$ $\mathrm{Hz}, 1 \mathrm{H}), 3.00(\mathrm{~d}, J=17.5 \mathrm{~Hz}, 1 \mathrm{H}), 1.41$ (s, 9H). ${ }^{13} \mathrm{C}$ NMR (126 MHz, DMSO-d 6 ) $\delta 169.89$, $162.35,155.86,144.70,136.96,126.57,126.22,125.16,124.93,78.75,60.99$, 58.95, 57.34, 42.91, 40.43, 35.76, 28.14, 24.29. HRMS (ESI): calcd for $\mathrm{C}_{25} \mathrm{H}_{29} \mathrm{O}_{6} \mathrm{~N}_{4} \mathrm{~S}_{2}\left[\mathrm{M}^{+}\right], m / z=545.15230$, found 545.15265. The purity of the compound was analyzed by analytical RP-HPLC (GeminiNX). Gradient starts from 5\% B for $4 \mathrm{~min}, 5 \%-100 \%$ B for $11 \mathrm{~min}$, wash. The product eluted at $11.6 \mathrm{~min}$ was detected at $\lambda=270 \mathrm{~nm}$.

Cephalosporin derivative 12a. RP-HPLC (Gemini-NX): Gradient 5\% B for $14 \mathrm{~min}$; 5\% - 40\% B for $46 \mathrm{~min} ; 40 \%-100 \% \mathrm{~B}$ for $5 \mathrm{~min}$, wash. The desired product eluting at 48.2 min was collected, and lyophilized to afford the product $\mathbf{1 2 a}(17 \mathrm{mg}, 0.057 \mathrm{mmol}, 49 \%)$ as a white solid. ${ }^{1}$ H NMR (500 MHz, MeOD) $\delta 9.10(\mathrm{~d}, J=6.6 \mathrm{~Hz}, 2 \mathrm{H}), 7.93(\mathrm{~d}, J=6.6 \mathrm{~Hz}, 2 \mathrm{H}), 7.25(\mathrm{dd}, J=$ 5.1, $1.1 \mathrm{~Hz}, 1 \mathrm{H}), 6.97-6.90(\mathrm{~m}, 2 \mathrm{H}), 5.69$ (d, $J=5.0 \mathrm{~Hz}, 1 \mathrm{H}), 5.67$ (d, J = 14.1 Hz, 1H), 5.18 $(\mathrm{d}, J=14.1 \mathrm{~Hz}, 1 \mathrm{H}), 5.07(\mathrm{~d}, J=5.0 \mathrm{~Hz}, 1 \mathrm{H}), 3.83-3.74(\mathrm{~m}, 2 \mathrm{H}), 3.58(\mathrm{~d}, J=17.8 \mathrm{~Hz}, 1 \mathrm{H})$, $3.09(\mathrm{~d}, J=17.8 \mathrm{~Hz}, 1 \mathrm{H}), 2.34(\mathrm{t}, J=7.6 \mathrm{~Hz}, 2 \mathrm{H}), 1.74-1.82(\mathrm{~m}, 3 \mathrm{H}), 1.69-1.58(\mathrm{~m}, 4 \mathrm{H}), 1.58$ - $1.50(\mathrm{~m}, 2 \mathrm{H}), 1.42$ - $1.32(\mathrm{~m}, 4 \mathrm{H}), 1.14-1.09(\mathrm{~m}, 2 \mathrm{H}) .{ }^{13} \mathbf{C}$ NMR (126 MHz, MeOD) $\delta$ $175.58,171.90,144.35,135.97,126.35,125.63,124.47,59.66,57.59,41.92,39.88,35.76,35.64$, 35.40, 32.33, 28.17, 25.66, 24.71. HRMS (ESI): calcd for $\mathrm{C}_{30} \mathrm{H}_{37} \mathrm{O}_{5} \mathrm{~N}_{4} \mathrm{~S}_{2}\left[\mathrm{M}^{+}\right], \mathrm{m} / z=597.21999$, found 597.22036. The purity of the compound was analyzed by analytical RP-HPLC. Gradient starts from 5\% B for $4 \mathrm{~min}, 5 \%-100 \%$ B for $16 \mathrm{~min}$, wash. The product eluted at $18.5 \mathrm{~min}$ was detected at $\lambda=270 \mathrm{~nm}$.

Cephalosporin derivative 12b. RP-HPLC (Gemini-NX): Gradient 5\% B for $14 \mathrm{~min} ; 5 \%$ - 40\% B for $46 \mathrm{~min}$; $40 \%$ - 100\% B for $5 \mathrm{~min}$, wash. The desired product eluting at 37-38 min was collected and lyophilized to afford product $\mathbf{1 2 b}(4.5 \mathrm{mg}, 0.101 \mathrm{mmol}, 7 \%)$ as a slightly yellowish solid.

${ }^{1} \mathbf{H}$ NMR (500 MHz, MeOD) $\delta 9.09(\mathrm{~d}, J=6.6 \mathrm{~Hz}, 2 \mathrm{H}), 7.95(\mathrm{~d}, J=6.6 \mathrm{~Hz}, 2 \mathrm{H}), 7.28-7.24(\mathrm{~m}$, 2H), $6.99-6.90(\mathrm{~m}, 4 \mathrm{H}), 5.70(\mathrm{~d}, J=5.0 \mathrm{~Hz}, 1 \mathrm{H}), 5.67(\mathrm{~d}, J=14.1 \mathrm{~Hz}, 1 \mathrm{H}), 5.19(\mathrm{~d}, J=14.1$ $\mathrm{Hz}, 1 \mathrm{H}), 5.09-5.04(\mathrm{~m}, 2 \mathrm{H}), 3.80(\mathrm{dd}, J=11.4,5.6 \mathrm{~Hz}, 4 \mathrm{H}), 3.63-3.53(\mathrm{~m}, 1 \mathrm{H}), 3.14-3.07$ $(\mathrm{m}, 1 \mathrm{H}), 2.47(\mathrm{dq}, J=12.4,6.2 \mathrm{~Hz}, 1 \mathrm{H}), 2.35(\mathrm{t}, J=7.4 \mathrm{~Hz}, 2 \mathrm{H}), 1.90(\mathrm{dq}, J=12.4,6.2 \mathrm{~Hz}, 1 \mathrm{H})$, 
$1.78-1.60(\mathrm{~m}, 4 \mathrm{H}), 1.54-1.45(\mathrm{~m}, 3 \mathrm{H})$. HRMS (ESI): calcd for $\mathrm{C}_{28} \mathrm{H}_{33} \mathrm{O}_{5} \mathrm{~N}_{4} \mathrm{~S}_{4}\left[\mathrm{M}^{+}\right], m / z=$ 633.13283, found 633.13297. The purity of the compound was analyzed by analytical RP-HPLC. Gradient starts from 5\% B for $4 \mathrm{~min}, 5 \%$ - 100\% B for $16 \mathrm{~min}$, wash. The product eluted at 16.5 min was detected at $\lambda=270 \mathrm{~nm}$.

Cephalosporin derivative 13a. RP-HPLC (Gemini-NX): Gradient 10\% B for $14 \mathrm{~min}$; 10\% - 50\% B for $36 \mathrm{~min}$; 50\% - 100\% B for 2 min, wash. The desired product eluting at 26.0-27.5 min was collected and lyophilized to afford product 13a (6.5 mg, $0.041 \mathrm{mmol}, 29 \%)$ as a white solid.

${ }^{1}$ H NMR (500 MHz, MeOD) $\delta 9.09(\mathrm{~d}, J=6.3 \mathrm{~Hz}, 2 \mathrm{H}), 7.92(\mathrm{~d}, J=6.3 \mathrm{~Hz}, 2 \mathrm{H}), 7.25(\mathrm{dd}, J=$ 5.1, $1.2 \mathrm{~Hz}, 1 \mathrm{H}), 6.96-6.90(\mathrm{~m}, 2 \mathrm{H}), 5.70(\mathrm{~d}, J=4.9 \mathrm{~Hz}, 1 \mathrm{H}), 5.67$ (d, $J=14.0 \mathrm{~Hz}, 1 \mathrm{H}), 5.18$ $(\mathrm{d}, J=14.0 \mathrm{~Hz}, 1 \mathrm{H}), 5.07(\mathrm{~d}, J=4.9 \mathrm{~Hz}, 1 \mathrm{H}), 3.82-3.75(\mathrm{~m}, 2 \mathrm{H}), 3.59(\mathrm{~d}, J=17.8 \mathrm{~Hz}, 1 \mathrm{H})$, $3.10(\mathrm{~d}, J=17.8 \mathrm{~Hz}, 1 \mathrm{H}), 2.78(\mathrm{p}, J=8.1 \mathrm{~Hz}, 1 \mathrm{H}), 1.98-1.88(\mathrm{~m}, 2 \mathrm{H}), 1.80-1.70(\mathrm{~m}, 4 \mathrm{H})$, $1.68-1.60(\mathrm{~m}, 2 \mathrm{H})$. HRMS (ESI): calcd for $\mathrm{C}_{26} \mathrm{H}_{29} \mathrm{O}_{5} \mathrm{~N}_{4} \mathrm{~S}_{2}\left[\mathrm{M}^{+}\right], m / z=541.15739$, found 541.15767. The purity of the compound was analyzed by analytical RP-HPLC (Gemini-NX). Gradient starts from 5\% B for $4 \mathrm{~min}, 5 \%$ - 100\% B for $11 \mathrm{~min}$, wash. The product eluted at 15.2 min was detected at $\lambda=270 \mathrm{~nm}$.

Cephalosporin derivative 14. RP-HPLC (Gemini-NX): Gradient 5\% B for 14 min; 5\% - 60\% B for $51 \mathrm{~min}$; $60 \%$ - 100\% B for $5 \mathrm{~min}$, wash. The desired product, eluting at 52-53 min, was collected, and lyophilized to afford product 14 (2 mg, $0.045 \mathrm{mmol}, 6 \%)$ as a yellow solid. ${ }^{1} \mathbf{H}$ NMR (500 MHz, DMSO-d $d_{6} \delta 9.42(\mathrm{~d}, J=6.5 \mathrm{~Hz}, 2 \mathrm{H}), 9.10(\mathrm{~d}, J=5.7 \mathrm{~Hz}, 1 \mathrm{H}), 9.07(\mathrm{~d}, J=8.3$ $\mathrm{Hz}, 1 \mathrm{H}), 7.94(\mathrm{~d}, J=6.5 \mathrm{~Hz}, 2 \mathrm{H}), 7.33(\mathrm{dd}, J=5.1,1.3 \mathrm{~Hz}, 1 \mathrm{H}), 6.92(\mathrm{dd}, J=5.1,3.4 \mathrm{~Hz}, 1 \mathrm{H})$, $6.89-6.87(\mathrm{~m}, 1 \mathrm{H}), 5.63(\mathrm{~d}, J=13.3 \mathrm{~Hz}, 1 \mathrm{H}), 5.55(\mathrm{dd}, J=8.3,4.9 \mathrm{~Hz}, 1 \mathrm{H}), 5.04(\mathrm{~d}, J=13.7$ $\mathrm{Hz}, 1 \mathrm{H}), 5.02(\mathrm{~d}, J=4.9 \mathrm{~Hz}, 1 \mathrm{H}), 4.57(\mathrm{~d}, J=5.5 \mathrm{~Hz}, 1 \mathrm{H}), 3.70(\mathrm{~d}, J=3.0 \mathrm{~Hz}, 2 \mathrm{H}), 3.52(\mathrm{~d}, J=$ $17.6 \mathrm{~Hz}, 1 \mathrm{H}), 3.08-2.95(\mathrm{~m}, 6 \mathrm{H}), 2.86(\mathrm{p}, J=7.1 \mathrm{~Hz}, 1 \mathrm{H}), 1.46(\mathrm{~s}, 18 \mathrm{H}) .{ }^{13} \mathrm{C} \mathrm{NMR}(126 \mathrm{MHz}$, DMSO) $\delta 172.13,169.92,167.85,163.28,163.02,162.61,159.35,149.42,144.64,138.59$, 136.97, 126.57, 126.23, 125.25, 124.92, 122.08, 108.50, 85.24, 60.93, 58.98, 57.35, 45.82, 41.82, 35.76, 31.89, 27.80, 24.31. HRMS (ESI): calcd for $\mathrm{C}_{34} \mathrm{H}_{43} \mathrm{O}_{9} \mathrm{~N}_{4} \mathrm{~S}_{4}[\mathrm{M}+\mathrm{H}]^{+}, m / z=779.19074$, found 779.19080. The purity of the compound was analyzed by analytical RP-HPLC (Gemini). Gradient starts from 5\% B for 4 min, 5\% - 100\% B for 11 min, wash. The product eluted at 16.2 min was detected at $\lambda=270 \mathrm{~nm}$.

\section{Synthesis of cephalosporin derivative $13 b$}


Cephalosporin derivative $14(4.7 \mathrm{mg}, 0.006 \mathrm{mmol})$ was dissolved in DCM $(0.450 \mathrm{~mL})$ and TFA $(0.140 \mathrm{~mL})$ was added. The reaction was stirred at $\mathrm{rt}$ for $1 \mathrm{~h}$. Then the solvent was evaporated and the crude product was washed with IPE $(2 \times 1 \mathrm{~mL})$. The crude product was dissolved in DMSO $(0.200 \mathrm{~mL})$ and the reaction mixture was stirred at $70{ }^{\circ} \mathrm{C}$ for $4 \mathrm{~h}$ in open flask. Methanol $(0.200 \mathrm{~mL})$ was added into the reaction. The mixture was filtered through the syringe filter (1.0 $\mu \mathrm{m}$ ) and purified by semi-prep RP-HPLC (Hydro): gradient 5\% B for 7 min; 5\% - 30\% B for 28 $\min ; 30 \%-100 \% \mathrm{~B}$ for $2 \mathrm{~min}$, wash. The desired product 13b, eluting at 25-30 min, was collected, and lyophilized to afford product as a yellowish solid (2.1 mg, $0.006 \mathrm{mmol}, 60 \%) .{ }^{1} \mathbf{H}$ NMR (500 MHz, DMSO-d $) \delta 9.41(\mathrm{~d}, J=6.2 \mathrm{~Hz}, 2 \mathrm{H}), 9.10-9.00(\mathrm{~m}, 2 \mathrm{H}), 7.97$ (d, $J=6.1 \mathrm{~Hz}$, 2H), $7.34(\mathrm{~d}, J=4.9 \mathrm{~Hz}, 1 \mathrm{H}), 6.92(\mathrm{dd}, J=3.5,4.9 \mathrm{~Hz}, 1 \mathrm{H}), 6.90-6.87(\mathrm{~m}, 1 \mathrm{H}), 5.64(\mathrm{~d}, J=$ $13.3 \mathrm{~Hz}, 1 \mathrm{H}), 5.54(\mathrm{dd}, J=8.3,4.8 \mathrm{~Hz}, 1 \mathrm{H}), 5.01(\mathrm{q}, J=4.2 \mathrm{~Hz}, 2 \mathrm{H}), 4.58(\mathrm{~d}, J=5.6 \mathrm{~Hz}, 2 \mathrm{H})$, $3.71(\mathrm{~d}, J=1.9 \mathrm{~Hz}, 2 \mathrm{H}), 3.52(\mathrm{~d}, J=17.6 \mathrm{~Hz}, 2 \mathrm{H}), 3.49-3.43(\mathrm{~m}, 3 \mathrm{H}), 3.00(\mathrm{~d}, J=17.6 \mathrm{~Hz}$, $1 \mathrm{H}), 1.03(\mathrm{~d}, J=6.1 \mathrm{~Hz}, 1 \mathrm{H})$. HRMS (ESI): calcd for $\mathrm{C}_{24} \mathrm{H}_{25} \mathrm{O}_{5} \mathrm{~N}_{4} \mathrm{~S}_{4}[\mathrm{M}]^{+}, m / z=577.07023$, found 577.07039. The purity of the compound was analyzed by analytical RP-HPLC (Gemini$\mathrm{NX}$ ). Gradient starts from 5\% B for $4 \mathrm{~min}, 5 \%-100 \% \mathrm{~B}$ for $11 \mathrm{~min}$, wash. The product eluted at 15.2 min was detected at $\lambda=270 \mathrm{~nm}$.

\section{Synthesis of cephalosporin derivative 11}

Under an argon atmosphere, a mixture of cephalothin 3 (46 mg, $0.115 \mathrm{mmol}$ ) and MSTFA $(0.040 \mathrm{~mL}, 0.216 \mathrm{mmol})$ in dry DCM $(0.700 \mathrm{~mL})$ in a Schlenk tube, was stirred at $\mathrm{rt}$ for $15 \mathrm{~min}$ until the cephalothin was dissolved. Then iodotrimethylsilane $(0.020 \mathrm{~mL}, 0.144 \mathrm{mmol})$ was added, and stirring was continued at $\mathrm{rt}$ for $1 \mathrm{~h}$. The mixture was concentrated under reduced pressure connected to Schlenk line, and the residual oil was dissolved in dry DMF (0.700 mL). A few drops of dry THF were added, and the mixture was stirred for 1 minute. Tert-butyl pyridin4-ylmethylcarbamate $(15 \mathrm{mg}, 0.072 \mathrm{mmol})$ dissolved in dry DMF $(0.700 \mathrm{~mL})$ was added and the reaction mixture was stirred at $\mathrm{rt}$ for $1 \mathrm{~h}$. The solvents were evaporated, the crude was resuspended in DCM $(0.500 \mathrm{~mL})$ and TFA $(0.200 \mathrm{~mL})$ was added. The mixture was stirred at $\mathrm{rt}$ for $1 \mathrm{~h}$. The solvent was evaporated and the mixture was dissolved in water/MeOH. The formed precipitate was filtered out and the solution was purified by preparative RP-HPLC (Hydro): gradient 5\% B for 14 min; 5\% - 15\% B for 16 min; 15\% - 100\% B for 3 min, wash. The desired product 11, eluting at 9-11 min, was collected and lyophilized to afford product $\mathbf{1 1}$ as a white solid (18 mg, $0.072 \mathrm{mmol}, 56 \%$ ). ${ }^{1} \mathbf{H}$ NMR (500 MHz, MeOD) $\delta 9.21$ (d, $\left.J=6.6 \mathrm{~Hz}, 2 \mathrm{H}\right), 8.16$ 
$(\mathrm{d}, J=6.6 \mathrm{~Hz}, 2 \mathrm{H}), 7.25(\mathrm{dd}, J=5.1,1.3 \mathrm{~Hz}, 1 \mathrm{H}), 6.97-6.91(\mathrm{~m}, 2 \mathrm{H}), 5.75(\mathrm{~d}, J=14.2 \mathrm{~Hz}$, $1 \mathrm{H}), 5.70(\mathrm{~d}, J=5.0 \mathrm{~Hz}, 1 \mathrm{H}), 5.32(\mathrm{~d}, J=14.2 \mathrm{~Hz}, 1 \mathrm{H}), 5.12(\mathrm{~d}, J=5.0 \mathrm{~Hz}, 1 \mathrm{H}), 4.53(\mathrm{~s}, 1 \mathrm{H})$, $3.83-3.75(\mathrm{~m}, 2 \mathrm{H}), 3.66(\mathrm{~d}, J=18.1 \mathrm{~Hz}, 1 \mathrm{H}), 3.20(\mathrm{~d}, J=18.1 \mathrm{~Hz}, 1 \mathrm{H}) .{ }^{13} \mathrm{C} \mathbf{N M R}(126 \mathrm{MHz}$, MeOD) $\delta 173.32,146.44,137.31,128.46,127.81,127.79,125.94,61.28,59.10,42.64,37.13$. HRMS (ESI): calcd for $\mathrm{C}_{20} \mathrm{H}_{21} \mathrm{O}_{4} \mathrm{~N}_{4} \mathrm{~S}_{2}\left[\mathrm{M}^{+}\right], m / z=445.09987$, found 445.09929. The purity of the compound was analyzed by analytical RP-HPLC (Gemini-NX). Gradient starts from 5\% B for $4 \mathrm{~min}, 5 \%-100 \% \mathrm{~B}$ for $11 \mathrm{~min}$, wash. The product eluted at $12.2 \mathrm{~min}$ was detected at $\lambda=270$ $\mathrm{nm}$.

\section{Procedure for the synthesis of cephalosporin derivatives with amino thiadiazol side chain}

General procedure. Under an argon atmosphere, NaI (3 equiv.) was added to a mixture of cephalosporin derivative 15 (1.5 equiv.) in dry acetone ( $0.1 \mathrm{M}$ solution). The reaction mixture was stirred at $\mathrm{rt}$ for $40 \mathrm{~min}$. Subsequently, the pyridine derivative (1 equiv.) in dry acetone $(0.1$ $\mathrm{M}$ solution) was added and the reaction was stirred at $\mathrm{rt}$ for $2-4 \mathrm{~h}$. After the reaction was finished, the solvent was evaporated and the mixture was washed with IPE $(2 \mathrm{~mL})$. The formed precipitate was filtered and then dissolved in mixture of DCM/anisole/TFA 5:1:1 (0.1 mL). The reaction mixture was stirred for $1-2 \mathrm{~h}$ and then IPE $(2 \mathrm{~mL})$ was added to the mixture. The resulting suspension was centrifuged. The supernatant was removed, and the precipitate was washed with IPE two more times. The crude was dissolved in mixture of $\mathrm{MeOH} / \mathrm{H}_{2} \mathrm{O} / \mathrm{CH}_{3} \mathrm{CN}$, filtered through a SPE column, and purified by preparative RP-HPLC. The purification methods, analytical data, and yields are below.

Cephalosporin derivative 17a. RP-HPLC (Gemini-NX): Gradient 5\% B for 14 min; 5\% - 45\% B for $46 \mathrm{~min} ; 45 \%$ - 100\% B for $5 \mathrm{~min}$, wash. The desired product, eluting at $41 \mathrm{~min}$, was collected and lyophilized to afford product $\mathbf{1 7 a}(9.2 \mathrm{mg}, 0.115 \mathrm{mmol}, 12 \%)$ as a white solid. ${ }^{1} \mathbf{H}$ NMR (500 MHz, MeOD) $\delta 9.09$ (d, $J=6.3 \mathrm{~Hz}, 2 \mathrm{H}), 8.49-8.44$ (m, 1H), 7.93 (d, $J=6.3 \mathrm{~Hz}$, 2H), $5.86(\mathrm{~d}, J=4.9 \mathrm{~Hz}, 1 \mathrm{H}), 5.67(\mathrm{~d}, J=13.8 \mathrm{~Hz}, 1 \mathrm{H}), 5.19$ (d, $J=13.8 \mathrm{~Hz}, 1 \mathrm{H}), 5.15(\mathrm{~d}, J=$ $4.9 \mathrm{~Hz}, 1 \mathrm{H}), 4.01(\mathrm{~s}, 3 \mathrm{H}), 3.60(\mathrm{~d}, J=17.8 \mathrm{~Hz}, 2 \mathrm{H}), 3.09$ (d, $J=17.8 \mathrm{~Hz}, 1 \mathrm{H}), 2.33$ (t, $J=7.6$ $\mathrm{Hz}, 1 \mathrm{H}), 2.36-2.25(\mathrm{~m}, 1 \mathrm{H}), 1.81-1.73(\mathrm{~m}, 4 \mathrm{H}), 1.68-1.59(\mathrm{~m}, 6 \mathrm{H}), 1.55-1.50(\mathrm{~m}, 2 \mathrm{H}), 1.38$ - $1.33(\mathrm{~m}, 3 \mathrm{H}), 1.17-1.04(\mathrm{~m}, 3 \mathrm{H})$. HRMS (ESI): calcd for $\mathrm{C}_{29} \mathrm{H}_{37} \mathrm{O}_{6} \mathrm{~N}_{8} \mathrm{~S}_{2}\left[\mathrm{M}^{+}\right], m / z=$ 657.22720, found 657.22748. The purity of the compound was analyzed by analytical RP-HPLC (Gemini-NX). Gradient starts from 5\% B for $4 \mathrm{~min}, 5 \%$ - 100\% B for $11 \mathrm{~min}$, wash. The product eluted at $14.7 \mathrm{~min}$ was detected at $\lambda=270 \mathrm{~nm}$. 
Cephalosporin derivative 17b. RP-HPLC: Gradient 10\% B for $14 \mathrm{~min}$; 10\% - 40\% B for $46 \mathrm{~min}$; $45 \%-100 \%$ B for $5 \mathrm{~min}$, wash. The desired product, eluting at $33.8 \mathrm{~min}$, was collected and lyophilized to afford product $\mathbf{1 7 b}(2.56 \mathrm{mg}, 0.067 \mathrm{mmol}, 6 \%)$ as a white solid. ${ }^{1} \mathbf{H}$ NMR (500 MHz, MeOD) $\delta 9.11(\mathrm{~d}, J=6.3 \mathrm{~Hz}, 2 \mathrm{H}), 8.92-8.88(\mathrm{~m}, 1 \mathrm{H}), 7.95(\mathrm{~d}, J=6.3 \mathrm{~Hz}, 2 \mathrm{H}), 5.79(\mathrm{~d}, J$ $=5.0 \mathrm{~Hz}, 1 \mathrm{H}), 5.69(\mathrm{~d}, J=15.3 \mathrm{~Hz}, 1 \mathrm{H}), 5.18(\mathrm{~d}, J=14.0 \mathrm{~Hz}, 1 \mathrm{H}), 5.14(\mathrm{~d}, J=4.9 \mathrm{~Hz}, 1 \mathrm{H}), 4.04$ (s, 3H), $3.21-3.15(\mathrm{~m}, 2 \mathrm{H}), 3.15-3.09(\mathrm{~m}, 2 \mathrm{H}), 2.50-2.41(\mathrm{~m}, 2 \mathrm{H}), 2.36(\mathrm{t}, J=7.4 \mathrm{~Hz}, 2 \mathrm{H})$, $2.34-2.28(\mathrm{~m}, 1 \mathrm{H}), 1.94-1.86(\mathrm{~m}, 2 \mathrm{H}), 1.77-1.60(\mathrm{~m}, 6 \mathrm{H}), 1.56-1.44(\mathrm{~m}, 4 \mathrm{H})$. HRMS (ESI): calcd for $\mathrm{C}_{27} \mathrm{H}_{33} \mathrm{O}_{6} \mathrm{~N}_{9} \mathrm{~S}_{4}[\mathrm{M}]^{+}, m / z=693.14004$, found 693.13968. The purity of the compound was analyzed by analytical RP-HPLC (Gemini-NX). Gradient starts from 5\% B for 4 $\min , 5 \%-100 \% \mathrm{~B}$ for $11 \mathrm{~min}$, wash. The product eluted at $15.3 \mathrm{~min}$ was detected at $\lambda=270 \mathrm{~nm}$. Cephalosporin derivative 18a. RP-HPLC (Gemini-NX): Gradient 5\% B for $14 \mathrm{~min}$; 5\% - 30\% B for $46 \mathrm{~min} ; 30 \%-100 \% \mathrm{~B}$ for $5 \mathrm{~min}$, wash. The desired product, eluting at $25.5 \mathrm{~min}$, was collected and lyophilized to afford product 18a (4.5 mg, $0.049 \mathrm{mmol}, 15 \%)$ as a white solid. ${ }^{1} \mathbf{H}$ NMR $\left(500 \mathrm{MHz}, \mathrm{DMSO}-d_{6}\right) \delta 9.46(\mathrm{~d}, J=8.3 \mathrm{~Hz}, 1 \mathrm{H}), 9.38(\mathrm{~d}, J=6.3 \mathrm{~Hz}, 2 \mathrm{H}), 8.61-8.59(\mathrm{~m}$, $1 \mathrm{H}), 8.12-8.08(\mathrm{~m}, 3 \mathrm{H}), 7.91(\mathrm{~d}, J=6.3 \mathrm{~Hz}, 2 \mathrm{H}), 5.65(\mathrm{dd}, J=8.5,5.0 \mathrm{~Hz}, 1 \mathrm{H}), 5.62(\mathrm{~d}, J=$ $13.5 \mathrm{~Hz}, 1 \mathrm{H}), 5.05(\mathrm{~d}, J=5.0 \mathrm{~Hz}, 1 \mathrm{H}), 5.02(\mathrm{~d}, J=14.1 \mathrm{~Hz}, 1 \mathrm{H}), 4.50(\mathrm{~d}, J=5.7 \mathrm{~Hz}, 2 \mathrm{H}), 3.85$ (s, 3H), $3.50(\mathrm{~d}, J=17.5 \mathrm{~Hz}, 1 \mathrm{H}), 2.98(\mathrm{~d}, J=17.5 \mathrm{~Hz}, 1 \mathrm{H}), 2.72-2.64(\mathrm{~m}, 1 \mathrm{H}), 1.85-1.78(\mathrm{~m}$, 2H), $1.69-1.59(\mathrm{~m}, 4 \mathrm{H}), 1.54-1.49(\mathrm{~m}, 2 \mathrm{H})$. HRMS (ESI): calcd for $\mathrm{C}_{25} \mathrm{H}_{29} \mathrm{O}_{6} \mathrm{~N}_{8} \mathrm{~S}_{2}\left[\mathrm{M}^{+}\right], m / z$ $=601.16460$, found 601.16508. The purity of the compound was analyzed by analytical RFHPLC (Gemini). Gradient starts from 5\% B for $4 \mathrm{~min}, 5 \%$ - 100\% B for $11 \mathrm{~min}$, wash. The product eluted at $12.1 \mathrm{~min}$ was detected at $\lambda=270 \mathrm{~nm}$.

Cephalosporin derivative 18b. Semi-prep RP-HPLC (Hydro): Gradient 5\% B for $7 \mathrm{~min}$; 5\% $30 \%$ B for $23 \mathrm{~min} ; 30 \%-100 \%$ B for $2 \mathrm{~min}$, wash. The desired product, eluting at $17.5 \mathrm{~min}$, was collected and lyophilized to afford product $\mathbf{1 8 b}(1.2 \mathrm{mg}, 0.083 \mathrm{mmol}, 2 \%)$ as a yellowish solid. ${ }^{1} \mathbf{H}$ NMR (500 MHz, MeOD) $\delta 9.10(\mathrm{~d}, J=6.5 \mathrm{~Hz}, 2 \mathrm{H}), 7.95(\mathrm{~d}, J=6.5 \mathrm{~Hz}, 2 \mathrm{H}), 5.85(\mathrm{~d}, J=4.9$ Hz, 1H), 5.69 (d, J = 13.5 Hz, 1H), 5.20 (s, 1H), 5.15 (d, J=5.0 Hz, 1H), 4.66 (s, 2H), 4.01 (s, $3 \mathrm{H}), 3.69-3.63(\mathrm{~m}, 2 \mathrm{H}), 3.61(\mathrm{~d}, J=17.8 \mathrm{~Hz}, 1 \mathrm{H}), 3.45-3.38(\mathrm{~m}, 5 \mathrm{H}), 3.10$ (d, J = $17.8 \mathrm{~Hz}$, 1H). HRMS (ESI): calcd for $\mathrm{C}_{23} \mathrm{H}_{25} \mathrm{O}_{6} \mathrm{~N}_{8} \mathrm{~S}_{4}\left[\mathrm{M}^{+}\right], m / z=637.07744$, found 637.07765. The purity of the compound was analyzed by analytical RP-HPLC (Gemini-NX): Gradient 5\% B for 4 min, $5 \%-100 \%$ B for $11 \mathrm{~min}$, wash. The product eluted at $13.8 \mathrm{~min}$ was detected at $\lambda=270 \mathrm{~nm}$.

\section{Biology}




\section{Bacterial strains and growth conditions.}

Bacillus subtilis (B. subtilis ATCC 6633), Staphylococcus aureus (S. aureus ATCC 25922, ATCC 29213, ATCC 43300 (MRSA)), Enterococcus faecalis (E. faecalis ATCC 51299 (VanB)), Escherichia coli (E. coli ATCC 25922, K12 MG1622), Pseudomonas aeruginosa (P. aeruginosa ATCC 27853, PAO1) was purchased from either the German Collection of Microorganisms and Cell Cultures (DSMZ) or the American Type Culture Collection (ATCC). The bacterial culture was stored at $-80{ }^{\circ} \mathrm{C}$, and new cultures were prepared by streaking on Mueller Hinton (MH) Agar, Luria-Bertani (LB) Agar, Trypsic Soy (TS) Agar plates. The overnight culture was prepared by inoculating a single colony into a sterile tube $(15 \mathrm{~mL})$ containing the $\mathrm{MH}, \mathrm{LB}$, or TS broth $(5 \mathrm{~mL})$ and the cultures were shaken $(200 \mathrm{rcf} / \mathrm{min})$ overnight at $37{ }^{\circ} \mathrm{C}$.

\section{Determination of Minimum Inhibitory Concentration (MIC)}

The minimum inhibitory concentration (MIC) was determined using the broth microdilution method according to the guidelines outlined by the European Committee on Antimicrobial Susceptibility Testing (EUCAST) standard protocol. ${ }^{25}$ See the Supporting Information for the detailed procedure.

\section{Defining conditions for biofilm inhibition assay.}

Biofilm production. The conditions for biofilm formation of S. aureus ATCC 29213, S. aureus ATCC 43300, and E. faecalis ATCC 51299 were published earlier. ${ }^{19}$ The overnight culture of E. coli (ATCC 25922, K12 MG1622) and P. aeruginosa (ATCC 27853, PAO1) was diluted in $\mathrm{LB}$ broth to $\mathrm{OD}_{600}=0.1-0.12$ corresponding to $10 \times 10^{8}$ cells $/ \mathrm{mL}$. The broths used for the experiment were prepared: Muller-Hilton broth (MHB), Trypsic Soy (TS), Trypsic Soy supplemented with $1 \%$ glucose (TSG), Trypsic Soy supplemented with $2 \%$ glucose (TS2G), Brain Heart Infusion (BHI), BHI supplemented with 1\% glucose (BHIG), M63 minimal supplemented with $\mathrm{MgSO}_{4}$, glucose and casamino acids (M63), M63 minimal supplemented with arginine (M63A). The adjusted to OD600 cells were diluted 1:100 with corresponding medium. An aliquot of $100 \mathrm{ul}$ of bacterial suspension per well was dispensed into a 96-well round bottom microplate. Microplates were then incubated at $37{ }^{\circ} \mathrm{C}$ for $24 \mathrm{~h}$.

Assessment of biofilm biomass by crystal violet.

An aliquot of $0.130 \mathrm{ul}$ of $0.1 \%$ solution of crystal violet in water was added in each well contained biofilm. The microplates were incubated for $10 \mathrm{~min}$ at $\mathrm{rt}$ and the plates were rinsed 2-3 
times with sterile water. The plates were left to dry for $2 \mathrm{~h}$ at rt. Next, $0.130 \mathrm{ul}$ of $30 \% \mathrm{AcOH}$ in water was added to each well of the microplate to solubilize the CV. The plates were incubated for $10 \mathrm{~min}$ at $\mathrm{rt}$. The obtained solutions were transferred into a new flat bottom 96-well plate. The absorbance was quantified at $570 \mathrm{~nm}$ using $30 \%$ acetic acid in water as the blank by a plate reader (Synergy H1 from BioTek). Assessment of metabolic activity of biofilm cells by fluorescein diacetate (FDA).

Biofilm production was performed using M63A for P. aeruginosa ATCC 27853. A stock of FDA (Across) was prepared at $1 \mathrm{mg} / \mathrm{mL}$ in DMSO, respectively. The solutions were filtersterilized and stored at $4{ }^{\circ} \mathrm{C}$ in the dark. Three concentrations of FDA solution were investigated: $2 \mu \mathrm{g} / \mathrm{mL}, 4 \mu \mathrm{g} / \mathrm{mL}$ and $8 \mu \mathrm{g} / \mathrm{mL}$ at $37{ }^{\circ} \mathrm{C}$. The diluted FDA solutions in PBS were prepared right before the assay. For the assay, firstly, biofilm was carefully washed with $200 \mu \mathrm{L}$ of sterile water. Next, $100 \mu \mathrm{L}$ of diluted FDA solutions were added into each well containing biofilm, along with its respective negative controls (un-inoculated broth, three wells). Microplates were placed in a plate reader to measure the kinetics of the reaction. The relative fluorescence units (RFU) $\left(\lambda_{\mathrm{Ex}}=490 \mathrm{~nm}\right.$ and $\lambda_{\mathrm{Em}}=526 \mathrm{~nm}$ ) were measured every $2 \mathrm{~min}$ for $2 \mathrm{~h}$ (Figure S, Supporting Information). The experiment was performed twice in triplicates. The optimal conditions were chosen based on the analysis of quality parameters ( $Z^{\prime} \square>\square 0.50$ ) calculated by the equations (Table S, Supporting Information).

\section{Determination of Minimum Biofilm Inhibitory Concentration (MBIC)}

Cephalosporin derivatives stock solutions were prepared in sterile water or water $+5 \%$ DMSO to a concentration of $1 \mathrm{mg} / \mathrm{mL}$. MBIC assay was performed by the broth microdilution method in 96-well round bottom microplate adapted from Clinical and Laboratory Standards Institute (CLSI) guideline. ${ }^{41}$

Bacterial suspension was diluted with BHIG broth to obtain an inoculum of $1 \times 10^{6} \mathrm{CFU} / \mathrm{mL}$. Two-fold serial dilutions of the compounds (ranging from $64 \mu \mathrm{g} / \mathrm{ml}$ to $0.06 \mu \mathrm{g} / \mathrm{ml}$ for cephalosporin derivatives) were prepared in BHIG (for S. aureus and E. faecalis) and M63A (for $P$. aeruginosa) to a final volume of $50 \mu \mathrm{l}$. The bacterial suspension $(50 \mu \mathrm{l})$ was added into each well on the microtiter plate for inoculation, corresponding to approximately $5 \times 10^{5} \mathrm{CFU} / \mathrm{ml}$. The plates were incubated without shaking for $24 \mathrm{~h}$ at $37{ }^{\circ} \mathrm{C}$, and $\mathrm{MBIC}$ was defined by performing the optimized resazurin or FDA assays (Table S, Supporting Information). CFUs were also 
determined after resazurin or FDA assays completion, in order to compare the results. The experiments were performed in triplicates.

\section{References}

1. Walsh, C. T. \& Wencewicz, T. A. Prospects for new antibiotics: a moleculecentered perspective. J. Antibiot. 67, 7-22 (2013).

2. Miethke, M. et al. Towards the sustainable discovery and development of new antibiotics. Nat. Rev. Chem. 5, 726-749 (2021).

3. O'Shea, R. \& Moser, H. E. Physicochemical Properties of Antibacterial Compounds: Implications for Drug Discovery. J. Med. Chem. 51, 2871-2878 (2008).

4. Richter, M. F. \& Hergenrother, P. J. The challenge of converting gram-positiveonly compounds into broad-spectrum antibiotics. Ann. N. Y. Acad. Sci. 1435, 18-38 (2019).

5. Recent examples from our group: Dailler, D., Dorst, A., Schäfle, D., Sander, P. \& Gademann, K. Novel fidaxomicin antibiotics through site-selective catalysis. Comm. Chem. 4, 1-11 (2021); Dorst, A. et al. Semisynthetic Analogs of the Antibiotics Fidaxomicin - Design, Synthesis, and Biological Evaluation. ACS Med. Chem. Lett. 11, 2414-2420 (2020); Dorst, A., Shchelik, I.S., Schäfle, D., Sander, P. \& Gademann, K. Synthesis and Biological Evaluation of Iodinated Fidaxomicin Antibiotics. Helv. Chim. Acta 103, e2000130 (2020); Wach, J.-Y., Bonazzi, S., \& Gademann, K. Antimicrobial Surfaces Through Natural Product Hybrids. Angew. Chem. Int. Ed. 47, 7123-7126 (2008).

6. Belousoff, M. J. et al. cryoEM-Guided Development of Antibiotics for DrugResistant Bacteria. ChemMedChem 14, 527-531 (2019).

7. Levy, S. B. \& Bonnie, M. Antibacterial resistance worldwide: Causes, challenges and responses. Nat. Med. 10, S122-S129 (2004). 
8. Martinez, J. L. \& Baquero, F. Mutation Frequencies and Antibiotic Resistance. Antimicrob. Agents Chemother. 44, 1771-1777 (2000).

9. Ito, A. et al. Siderophore Cephalosporin Cefiderocol Utilizes Ferric Iron Transporter Systems for Antibacterial Activity against Pseudomonas aeruginosa. Antimicrob. Agents Chemother. 60, 7396-7401 (2016).

10. Saisho, Y., Katsube, T., White, S., Fukase, H. \& Shimada, J. Pharmacokinetics, safety, and tolerability of cefiderocol, a novel siderophore cephalosporin for gramnegative bacteria, in healthy subjects. Antimicrob. Agents Chemother. 62, e0216317 (2018).

11. Hancock, R. E. W. Alterations in Outer Membrane Permeability. Ann. Rev. Microbiol. 38, 237-264 (1984).

12. Laurent, Q. et al. Probing for Thiol-Mediated Uptake into Bacteria. ChemBioChem 21, 69-73 (2020).

13. Laurent, Q. et al. Thiol-Mediated Uptake. JACS Au 1, 710-728 (2021).

14. Donlan, R. M. \& Costerton, J. W. Biofilms: Survival Mechanisms of Clinically Relevant Microorganisms. Clin. Microbiol. Rev. 15, 167-193 (2002).

15. Costerton, J. W., Stewart, P. S. \& Greenberg, E. P. Bacterial biofilms: A common cause of persistent infections. Science 284, 1318-1322 (1999).

16. Algburi, A., Comito, N., Kashtanov, D., Dicks, L. M. T. \& Chikindas, M. L. Control of Biofilm Formation: Antibiotics and Beyond. Appl. Envir. Microbiol. 83, e02508-16 (2017).

17. Jakobsen, T. H. et al. Ajoene, a sulfur-rich molecule from garlic, inhibits genes controlled by quorum sensing. Antimicrob. Agents Chemother. 56, 2314-2325 (2012).

18. Danquah, C. A. et al. Analogues of Disulfides from Allium stipitatum Demonstrate Potent Anti-tubercular Activities through Drug Efflux Pump and Biofilm Inhibition. Sci. Rep. 8, (2018).

19. Shchelik, I. S. \& Gademann, K. Thiol- and Disulfide-Containing Vancomycin Derivatives Against Bacterial Resistance and Biofilm Formation. ACS Med. Chem. Lett. (2021) doi:10.1021/acsmedchemlett.1c00455. 
20. Newton, G. G. F. \& Abraham, E. P. Cephalosporin C, a new antibiotic containing sulphur and D- $\alpha$-aminoadipic acid. Nature 175, 548 (1955).

21. Abraham, E. P. \& Newton, G. G. F. The structure of cephalosporin C. Biochem. J. 79, 377-393. (1961).

22. Tipper, D. J. \& Strominger, J. L. Mechanism of action of penicillins: a proposal based on their structural similarity to acyl-D-alanyl-D-alanine. PNAS 54, 1133$1141(1965)$.

23. Hughes, D. L. Patent Review of Manufacturing Routes to Fifth-Generation Cephalosporin Drugs. Part 1, Ceftolozane. Org. Process Res. Dev. 21, 430-443 (2017).

24. Roberts, J. Cephalosporins. in Kirk $\square$ Othmer Encyclopedia of Chemical Technology (John Wiley \& Sons, Inc., 2000), DOI: 10.1002/0471238961.0305160818150205.a01

25. EUCAST reading guide for broth microdilution. www.eucast.org (2021).

26. Yamazaki, H., Tsuchida, Y. \& Satoh, H. Novel Cephalosporins 2. Synthesis of 3Heterocyclic-fused Thiopyranylthiovinyl Cephalosporins and Antibacterial Activity against Methicillin-resistant Staphylococcus aureus and Vancomycin-resistant Enterococcus faecalis. J. Antibiot. 53, 551-555 (2000).

27. Høiby, N., Ciofu, O. \& Bjarnsholt, T. Pseudomonas aeruginosa biofilms in cystic fibrosis. Appl. Envir. Microbiol. 5, 1663-1674 (2010).

28. Archer, N. K. et al. Staphylococcus aureus biofilms. Virulence 2, 445-459 (2011).

29. Cady, N. C. et al. Inhibition of Biofilm Formation, Quorum Sensing and Infection in Pseudomonas aeruginosa by Natural Products-Inspired Organosulfur Compounds. PLoS ONE 7, 38492 (2012).

30. Li, W.-R. et al. Diallyl disulfide from garlic oil inhibits Pseudomonas aeruginosa virulence factors by inactivating key quorum sensing genes. Front. Microb. 102, (2018).

31. Hentzer, M. et al. Attenuation of Pseudomonas aeruginosa virulence by quorum sensing inhibitors, EMBO J., 22, 3803-3815 (2003). 
32. Cruz, C. D., Shah, S. \& Tammela, P. Defining conditions for biofilm inhibition and eradication assays for Gram-positive clinical reference strains. BMC Microb. 18, (2018).

33. O’Toole, G. A. Microtiter Dish Biofilm Formation Assay. J. Vis. Exp. 47, 2437 (2011).

34. Peeters, E., Nelis, H. J. \& Coenye, T. Comparison of multiple methods for quantification of microbial biofilms grown in microtiter plates. J. Microb. Methods 72, (2008).

35. Nicolaou, K. C., Hughes, R., Pfefferkorn, J. A. \& Barluenga, S. Optimization and Mechanistic Studies of Psammaplin A Type Antibacterial Agents Active against Methicillin-ResistantStaphylococcus aureus (MRSA). Chem. Eur. J. 7, 4296-4310 (2001).

36. Buckwell, S. C., Page, M. I., Waley, S. G. \& Longridge, J. L. Hydrolysis of 7substituted cephalosporins catalysed by $\beta$-lactamases I and II from Bacillus cereus and by hydroxide ion. J. Chem. Soc., Perkin Trans. 2, 1815-1821 (1988).

37. Tsushima, M. et al. Novel cephalosporin derivatives possessing a bicyclic heterocycle at the 3-Position. Part II: Synthesis and antibacterial activity of 3-(5Methylthiazolo[4,5- c ]pyridinium-2-yl)thiomethylcephalosporin derivatives and related compounds. Bioorg. Med. Chem. 6, 1641-1653 (1998).

38. Shchelik, I. S., Tomio, A. \& Gademann, K. Design, Synthesis, and Biological Evaluation of Light-Activated Antibiotics. ACS Inf. Dis. 7, 681-692 (2021).

39. Koufaki, M. et al. Novel Potent Inhibitors of Lipid Peroxidation with Protective Effects against Reperfusion Arrhythmias. J. Med. Chem. 44, (2001).

40. Tirla, A., Hansen, M. \& Rivera-Fuentes, P. Synthesis of Asparagusic Acid Modified Lysine and its Application in Solid-Phase Synthesis of Peptides with Enhanced Cellular Uptake. Synlett 29, 1289-1292 (2018).

41. M07-A10 Methods for Dilution Antimicrobial Susceptibility Tests for Bacteria That Grow Aerobically; Approved Standard-Tenth Edition. www.clsi.org. (2015).

\section{Acknowledgements}


The authors acknowledge the Swiss National Science Foundation (SNSF, Grant 182043) and a Bundesstipendium for financial support. We thank Laura Kqiku for initial experiments not included in this study. The authors acknowledge the NMR and mass spectrometry facilities at the University of Zurich for training and maintenance of the instruments.

\section{Author Contributions}

I.S.S. and K.G. designed the study, I.S.S. performed all experiments, I.S.S. and K.G. analyzed the data, and I.S.S. and K.G. wrote the manuscript.

\section{Competing interests}

The authors declare no competing interests. 